
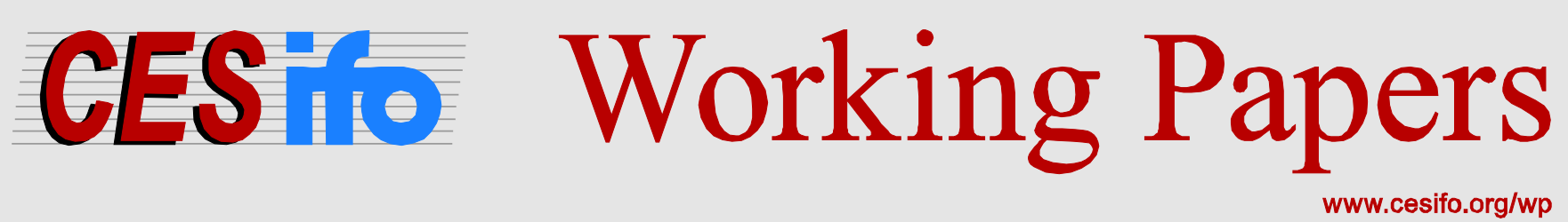

\title{
Rent Taxes and Royalties in Designing Fiscal Regimes for Non-Renewable Resources
}

\author{
Robin Boadway \\ Michael Keen
}

CESIFO WORKING PAPER NO. 4568

CATEGORY 1: PUBLIC FinANCE

JANUARY 2014

An electronic version of the paper may be downloaded

- from the SSRN website:

- from the RePEc website:

- from the CESifo website:

wWw.SSRN.com

www.RePEc.org

www.CESifo-group.org/wp

\section{CESifo}




\title{
Rent Taxes and Royalties in Designing Fiscal Regimes for Non-Renewable Resources
}

\begin{abstract}
A fundamental issues in designing any fiscal regime for non-renewable resources is the balance between rent taxes and royalties. This paper reviews the core issues that arise, in terms of both efficient rent extraction and correcting various market failures. Issues of asymmetric information, for instance, can rationalize using both instruments. The paper also shows that, even though they effectively involve the choice of distinct parameters at several dates, rent taxes are not subject to the time consistency problem that is central to the extractive industries, but royalties are (although time consistent royalty policy is efficient conditional on initial resource stocks).
\end{abstract}

JEL-Code: H210, H250, Q300.

Keywords: rent tax, royalties, resource taxation.

\author{
Robin Boadway \\ Department of Economics \\ Queen's University \\ Dunning Hall \\ Canada - K7L 3N6 Kingston, Ontario \\ boadwayr@econ.queensu.ca
}

\author{
Michael Keen \\ Fiscal Affairs Department \\ International Monetary Fund \\ 700 19th Street NW, Room 4-700 \\ USA - 20431 Washington DC \\ mkeen@imf.org
}

December 2013

To appear in David Layton and Robert Halvorsen (eds), Handbook on the Economics of Natural Resources (Edward Elgar). We are grateful to Joseph Bell, Bob Conrad, and Philip Daniel for their comments and suggestions. The views expressed here are the authors' alone, and should not be attributed to the IMF, its Executive Board, or management. 


\section{INTRODUCTION}

The taxation of non-renewable natural resources - meaning, for present purposes, petroleums (oil and gas) and minerals - is an important source of government revenue for many countries, including increasingly many developing ones. For example, over 80 percent of government revenue comes from petroleum in several Middle East countries as well as Brunei and Equatorial Guinea; 45 percent comes from mining in Botswana; and about onequarter of government revenue comes from mining and petroleum combined in Bolivia, Democratic Republic of Congo, Indonesia, Papua New Guinea, Russia, and Vietnam; and major new discoveries have been made in Ghana, Uganda, and elsewhere (IMF, 2012a). Lesser, but still significant, revenue contributions from nonrenewable natural resource are found in several OECD countries, including Australia, Canada, Norway, and the United Kingdom. The design of natural resource revenue regimes is of thus of considerable importance in a large and diverse range of countries.

Natural resource revenues are obtained by a variety of different instruments, including royalties, profit or rent taxes, production sharing arrangements, auction of exploration and production leases, excise and trade taxes, production by state-owned firms, and state participation through paid-up equity or carried interest (under which the state pays for an equity stake through its share of profits). As well, revenues from natural resource activities accrue through more general forms of taxation, such as customs duties and personal and corporate income tax. Our focus in this paper is on the conceptual issues around the two main sector-specific taxes: royalties (sometimes referred to as 'severance payments') and rent taxes. ${ }^{2}$ A fuller treatment of different ways of recouping revenues from exhaustible resources, with an eye on actual practice, may be found in the various contributions in Daniels, Keen, and McPherson (2010).

Carving out rent taxes and royalties for detailed treatment is useful pedagogically because they are commonly at the core of fiscal regimes for renewable resources; and much sometimes heated discussion revolves around precisely the proper roles of the two. The basic distinction between them is conceptually clear. Rent taxes are charges on pure profits (here, of course, the focus is on natural resource firms, though such taxes could apply to any enterprise)—-that is, on revenues less all imputed costs. Archetypal royalties, on the other hand, are charges on either the physical quantity or the value of output. In practice, however, the distinction among tax types is not so clean-cut. Charges labeled as a 'rent tax' come in many different forms, some of which only tax rents imperfectly; and the standard corporate

\footnotetext{
${ }^{2}$ While we do not address practical issues of implementation, these are (or should be) rarely determinative, even where administrative capacity is not strong: as discussed in Calder (forthcoming), rent taxes are not necessarily as hard to apply as one might suppose — as will to some degree become evident below—and royalties are not necessarily as easy.
} 
income tax itself bears partly on rents. Moreover, some revenue instruments not so labeled are equivalent to rent taxes or royalties. ${ }^{3}$ Royalties themselves sometimes include elements of rent taxation, such as when the royalty applies to revenues less some components of cost. These subtleties are discussed in more detail in Boadway and Keen (2010), which this paper draws on and extends. ${ }^{4}$

Our approach is to emphasize analytical issues arising in the use of rent taxes and royalties in natural resource industries, concentrating especially on their efficiency properties in stylized models designed to capture important real-world features of tax design. As such, there are a number of aspects we do not touch on, and it is worthwhile highlighting them before we turn to our analysis. The tax forms we analyze are simple in structure, and are analyzed in abstract partial equilibrium settings involving firms engaged in developing and extracting a natural resource from a single deposit. We leave out many important details that apply in practice, such as the treatment of large vertically and/or horizontally integrated resource firms, where the issue of defining the taxpaying unit is relevant (e.g., project versus firm). The firms we analyze engage in a simplified form of production involving some homogeneous initial investment followed by an extraction phase with a single output. The processing of the resource is ignored, as is the possibility of mines with multiple types of minerals. Two distinguishing features of natural resource production - the length of the production process and the uncertainty of resource prices - are included in as simple a way as is consistent with developing their policy implications.

Finally, we do not deal with the disposition of the revenues obtained from natural resources. In the case of non-renewable natural resources, two issues arise. One is the extent to which resource revenues should go into the government's general revenues to be used for current purposes as opposed to being saved for future generations, who have a legitimate claim to resource ownership; recent treatments of this issue are in Venables (2010) and IMF (2012b). The second is the extent to which natural resource revenues lead to wasteful expenditures, costly rent-seeking behavior and, not infrequently, corrupt governance practices; a review of these important issues may be found in van der Ploeg (2011). More generally, our analysis is normative in nature. We do not attempt to address the political economy determinants of natural resource taxation, although these are obviously of some relevance in practice, and

\footnotetext{
${ }^{3}$ Carried interest arrangements, for instance, are effectively a rent tax (of the Brown form discussed below) so long as interest is payable on the government's contribution; and production sharing with a binding limit on the absolute amount of costs that the extracting firm can recover is equivalent to a royalty. Daniel (1995) discusses these and other fiscal equivalencies.

${ }^{4}$ Useful though in some cases now somewhat dated surveys are also provided by Heaps and Helliwell (1985), who also cover the taxation of renewable resources, such as fisheries and forests (on which see too Dasgupta and Heal (1979)), Krautkraemer (1999), Smith (2012a), whose treatment encompasses engineering-based approaches rather different from the Hotelling tradition followed here, and, with a focus on rent taxation, Lund (2009).
} 
may temper advice given to policy-makers. Nor do we discuss the consequences of the fact that natural resources are often concentrated in specific regions of a country, which raises intriguing issues concerning the appropriate extent and nature of decentralized policy-making and revenue allocation.

We begin with an analysis of revenue-raising in a context in which natural resource production in the absence of taxes is fully efficient, dealing in turn with unfettered use of rent taxes (in Section II) and royalties (Section III) in such a setting. Section IV then turns to two sorts of complications. In one, market inefficiencies, such as imperfect risk-sharing and differences in public-private discount rates, exist so that natural resource taxation not only raises revenue but also addresses distortions. In the other, tax policy itself is constrained by asymmetric information and the inability of the government to commit to future tax rates. Section V briefly concludes.

\section{TAXING RENTS}

\section{A. The framework of the analysis}

Natural resources provide an opportunity, rare though, perhaps not unique, among revenue sources, to raise revenue in a non-distorting manner. This is because by their very nature natural resources are fixed in supply and immobile geographically. The economic value of a resource, after accounting for all the costs of discovering, developing, and extracting it, takes the form of a rent. A properly designed tax should in principle be able to capture some or even all of this rent for the public sector. In this section, we explore ways in which a tax on rents can be designed. To focus on the key features of a rent tax, we begin in an idealized world whose features are such that the government has the ability to implement an efficient tax on rents, and which is simple enough to enable the derivation of clear analytical results. Thus, our analysis is partial equilibrium and focuses on a resource firm in a competitive price-taking environment. Given the lengthy timeline involved in resource production, the firm faces uncertain prices and costs, but it is risk-neutral and capital markets are efficient. The technology is simplified so that the producer incurs capital costs for exploration and development up front, and only current costs of extraction as the resource is being exploited. We abstract too, throughout the paper, from environmental or other externalities (which are in principle readily handled by targeted tax measures).

The government is equally stylized. It is assumed throughout to be benevolent, and (until Section IV) to be risk-neutral, to value cash flows in exactly the same way as does the firm, to be perfectly informed, and to be able to commit to the tax policy it announces regardless of new information that becomes available in the future. All these assumptions imply that, for the present - and things will be very different in Section IV - the firm's choices in the absence of taxation would be fully efficient. The only rationale for government intervention in the sector is to raise revenues — for which it will evidently wish to capture rents with as little distortion to the firm's behavior as it can. 
There are some important institutional issues that underlie the simple model we present. We treat the resource producer as if it were a vertically integrated firm that engages in all stages of production including exploration, development, and extraction. This is for more than simplicity. The rent of a resource deposit is its value net of the full opportunity costs of obtaining it, so the costs at all stages of production must be accounted for. In practice, exploration is often done by a different firm from that which develops and extracts the resource. Efficiency requires that the tax system integrates the costs and revenues of different firms involved in the production process, for example, by taking account of the value of inter-firm transactions. By the same token, a single firm might be involved in the production of different resource projects. The tax system may treat each resource project as separate taxable entities, or it may tax the multi-project firm in a consolidated form. As long as all costs and revenues are accounted for, that distinction should not be important for efficiency. Special problems arise from the fact that exploration is highly risky, given that the proportion of successful discoveries is relatively small (though vertical and horizontal integration can make less likely failures by individual exploration firms). An efficient tax system must treat the costs incurred by loss-making firms or projects in the same manner as those of profitable ones. By assuming that full loss offsetting applies, which is required for efficiency, the firm's organization will not matter for our analysis, given that we assume risk neutrality and ignore the transaction costs of starting new firms and closing unsuccessful ones.

Finally, we focus solely on resource taxes narrowly defined. We do not take account of other taxes, like corporate income taxes, value-added taxes, and property taxes. Nor do we include other ways that rents can be diverted to the public sector, such as through the auctioning of rights to exploration and development, production sharing agreements, or equity participation — all of which can be made fiscally equivalent to a tax on rents. These are discussed in detail in Daniel, Keen, and McPherson (2010). Our analysis is of the government imposing a tax on resource-producing private firms for the purpose of obtaining

a share of the rents. Initially, we focus separately on the two main forms of resource taxation: rent taxes in this section and royalties in the next. In practice, both forms of tax may coexist, and we later consider some reasons why that might be the case.

\section{B. The multiplicity and design of rent taxes}

Designing a tax that applies in each period to rents as they are usually defined would be virtually impossible. Economic rents or profits in a given period are the difference between accrued revenues and accrued costs, where the latter include both current costs and the opportunity costs of the use of assets in the period. Measuring the costs of asset use each period is practically impossible, since it would involve not only measuring the economic depreciation of physical capital, but also the imputed cost of depleting resource stocks now rather than later (the excess of revenues over these costs being known as 'Hotelling rent'). Fortunately, there are convenient alternatives that are equivalent in present-value terms, and that are administratively feasible, at least under the assumptions we adopt. 
To facilitate the analysis, it is useful to spell out what the objective of the firm is. Suppose credit markets are competitive and that resource firms can borrow and lend at a competitive risk-free interest rate $r$. (This neglects the possibility of personal bankruptcy of resource firm owners, which may not be fully realistic in the case of prospectors and other small operators.) Then, in the absence of taxes, a firm that maximizes the present value of economic rents can equivalently be viewed as maximizing the present value of cash flows using the discount rate $r .{ }^{5}$ This is because with competitive credit markets, all rents accrue to the firm's shareholders. Given that, a tax that applies to cash flows will be equivalent to a rent tax, an equivalence that we exploit more formally below. A tax based on cash flows avoids the need to use accrual accounting, as well as the requirement to measure depreciation and resource depletion costs. It also conveniently allows one to ignore financial transactions of the firm.

\section{A model of a resource firm with no taxes}

Consider the following prototypical resource firm starting up in period zero. In that period, it chooses some level of investment $I$ whose relative price in terms of numeraire consumption is unity. For simplicity, we assume that this investment creates with certainty an initial natural resource stock given by $\bar{S}(I)$, with $\bar{S}^{\prime}(I)>0>\bar{S}^{\prime \prime}(I)$, the prime denoting differentiation. Adding uncertainty to the outcome of initial investment would be realistic, but is inessential to our main argument. Beginning in period one, the firm starts to extract the resource. Let $q_{t}$ be the quantity extracted in period $t$, and assume this is sold in the same period at a price $p_{t}$. The cost of extraction is $C\left(q_{t}, S_{t}\right)$, which is increasing and convex in $q_{t}$ and decreasing in $S_{t}$, the stock available in period $t$. Costs could include both current and capital costs, but for simplicity do not lead to any further increase in stocks. The stock evolves according to $S_{t+1}=S_{t}-q_{t}$, and must satisfy an exhaustibility constraint $\sum_{t=1}^{T} q_{t} \leq$ $\bar{S}(I)$, where $T$ is the period in which the firm decides to cease production permanently. Both $p_{t}$ and $C\left(q_{t}, S_{t}\right)$ can be stochastic.

It is instructive to characterize as a benchmark the firm's dynamic behavior in the absence of taxes. In period $t \geq 1$, given the information about prices and costs available then, the value of the firm is based on its cash flows and is given as:

$$
V_{t}\left(S_{t}\right)=\max _{\left\{q_{t}\right\}}\left\{p_{t} q_{t}-C\left(q_{t}, S_{t}\right)+\frac{1}{1+r} E_{t}\left[V_{t+1}\left(S_{t+1}\right)\right]\right\}
$$

\footnotetext{
${ }^{5}$ The equivalence between maximizing the present value of cash flows and maximizing the wealth of shareholders is discussed in detail in Auerbach (1979, 1983).
} 
where $S_{t+1}=S_{t}-q_{t}$, and $E_{t}\left[V_{t+1}\left(S_{t+1}\right)\right]$ is the expectation in period $t$ of the value of the firm in period $t+1$; for brevity, we ignore the obvious non-negativity condition on the $q_{t}$. The optimal choice of $q_{t}$ satisfies the following first-order condition:

$$
p_{t}-C_{q}(t)=\frac{1}{1+r} E_{t}\left[V_{S}(t+1)\right]
$$

where, for simplicity, $C_{q}(t)$ and $V_{S}(t+1)$ denote the derivatives $C_{q}\left(q_{t}, S_{t}\right)$ and $V_{t+1}^{\prime}\left(S_{t+1}\right)$. Applying the envelope theorem to (1) we obtain:

$$
V_{S}(t)=-C_{S}(t)+\frac{1}{1+r} E_{t}\left[V_{S}(t+1)\right]
$$

Taking the expectation of (2) and (3) one period forward, and using these to eliminate the $V_{S}(\cdot)$ terms, we obtain:

$$
\frac{E_{t}\left[p_{t+1}-C_{q}(t+1)\right]-\left(p_{t}-C_{q}(t)\right)}{p_{t}-C_{q}(t)}=r+\frac{E_{t}\left[C_{S}(t+1)\right]}{p_{t}-C_{q}(t)} .
$$

This is a version of the well-known Hotelling (1931) rule for resource extraction. It says that the rate of resource extraction will be such that the expected rate of change in the price of the resource net of extraction cost equals the interest rate less a term involving the increase in the extraction cost as the stock is depleted. In the special case where there are no extraction costs, (4) reduces to the familiar form:

$$
\frac{E_{t}\left[p_{t+1}\right]-p_{t}}{p_{t}}=r .
$$

That is, the expected price rises at the interest rate. Since firms are price-takers, each would go to a corner solution if this equality were not satisfied. It can therefore be interpreted as an equilibrium condition for the industry as a whole. In what follows, we shall focus on the more general condition in (4).

The Hotelling rule (4) applies as long as the firm continues to extract some positive amount of the resource. It could be that in some periods the price is so low or costs so high that it is privately optimal to set extraction temporarily to zero. More fundamentally, and assuming there to be free disposal of any remaining resource stock and no terminal clean-up or other terminal costs, the firm will permanently shut down operations at the earliest date at which $V\left(S_{t}\right)<0$. (That the shutdown is expected to be permanent follows on noting that $V\left(S_{t}\right)$ can never have any strictly positive probability of turning positive after it has become negative, since if it did that would imply strictly positive value at all earlier dates.) 
Eq. (4) combined with this shutdown condition characterizes the pattern of extraction. The actual path depends on the initial stock $\bar{S}(I)$, which is a matter of choice. The value of the firm in period zero is given by:

$$
V_{0}=\max _{\{I\}}\left\{-I+\frac{1}{1+r} E_{0}[V(1)]\right\}
$$

where the argument of $V(1)$ is $S_{1}=\bar{S}(I)$. The first-order condition for this gives:

$$
\frac{1}{1+r} E_{0}\left[V_{S}(1)\right] \bar{S}^{\prime}(I)=1
$$

This is intuitive: the present value of the expected private benefit of the marginal investment at time zero-its marginal $Q$ value-equals its cost. If the function $\bar{S}(I)$ were stochastic, as of course it is in reality, the interpretation could readily take that into account by putting $\bar{S}^{\prime}(I)$ inside the expectations operator in (5). Such uncertainty would add an important consideration into the design of resource taxes. Uncertainty in resource discovery would lead to some exploration expenditures yielding no resource discoveries, or equivalently having negative rents. ${ }^{6}$ When we consider rent taxes below, such investments should be expensed for tax purposes and afforded a refundable tax credit or its equivalent for the tax system to be fully efficient. Otherwise, exploration would be subject to downside risk and discouraged. Note that this applies even where the firm is risk-neutral, as we are assuming here.

An alternative way to characterize the initial investment decision is to derive an expression for the valuation of the firm in any period. This can readily be done in the special case where extraction costs are independent of $S_{t}$, so can be written $C\left(q_{t}\right)$. Combining (2) and (3) and using the fact that $C_{S}(t)=0$, we obtain:

$$
p_{t}-C_{q}(t)=V_{S}(t)
$$

This is a linear differential equation in $S_{t}$ whose solution is:

$$
V\left(S_{t}\right)=\left(p_{t}-C_{q}(t)\right) S_{t}+A
$$

If $V(0)=0$, then $A=0$, and rearranging yields:

\footnotetext{
${ }^{6}$ There is an important conceptual issue here. If there were virtually no information about the likelihood of success in exploration, free entry of exploration firms would result in zero expected profits from resources. Expected revenues from a rent tax would be zero. In the real world, there is presumably some information about the likelihood of success in particular areas, possibly because of government surveys or because of discoveries by other firms. In these circumstances, expected rents are positive, and the auction of leases, or equivalently the ex post taxation of rents would yield positive expected revenues.
} 


$$
V\left(S_{t}\right)=\left(\frac{p_{t}-C_{q}(t)}{p_{t}}\right) p_{t} S_{t}
$$

This is the Hotelling valuation principle: in the absence of taxes, and with extraction costs independent of the stock of the resource remaining in the ground, the value of the firm at time $t$ is simply the market value of reserves at that date multiplied by a markup factor that again depends only on $t$-dated variables. With extraction fully efficient at all dates, the current-dated terms on the right of this expression in effect provide a summary statistic for expected profits at all future dates.

A further striking implication follows on recalling (6), the condition for optimal investment. Since $V_{S}(1)=p_{1}-C_{q}(1)$, this becomes:

$$
\frac{1}{1+r} E_{0}\left[p_{1}-C_{q}(1)\right] \bar{S}^{\prime}(1)=1
$$

When the cost of extraction does not depend on the stock of the resource, investment depends only on expected first-period prices and marginal extraction costs: once again, the expectation of fully efficient extraction means that near-term prices and costs effectively summarize all that need be known of future possibilities and actions.

This completes our discussion of the optimal investment, extraction, and shutdown decisions of the resource firm in the absence of taxes. We have used a very stylized model incorporating these decisions in the simplest of ways because it provides a convenient benchmark for comparing rent taxes and royalties. Before turning to that comparison, it is useful to highlight some ways in which our model can be revised to take account of alternative features of real-world non-renewable resource production. As we have noted, the benefits of exploration are uncertain. Adding this would be relatively straightforward, and will reinforce the importance of loss offsetting. Investment will occur in practice over a number of initial periods, and also during periods of extraction. This would especially complicate our analysis if there were adjustment costs associated with changes in the level of investment. Related to that, we have assumed that the firm is free to change its rate of extraction to satisfy the Hotelling condition (2) in every period. For some types of natural resources, the per-period level of extraction is relatively fixed from one period to another. We consider below the extreme case where the rate of extraction is fixed once production starts, but at a level that depends on initial investment. Rather than focusing on the rate of extraction once production starts, firms might change inventory holdings as a way to react to variations in prices. It would be relatively straightforward to take this into account. We have taken as given the start-up time for both initial investment and extraction. Given that resource prices are uncertain, firms may have an advantage in waiting until prices are sufficiently high before proceeding. Lund (2005) has used option-pricing theory to study the optimal start-up time for resource projects in simple models. Our comparison between rent taxes and royalties 
will survive this extension. We briefly explore the consequences of relaxing these assumptions below.

We now turn to tax schemes for extracting the rent from the resource firm for the public sector. In doing so, we assume for the moment that the government values net cash flows exactly as does the private firm: it is also risk-neutral, for instance, and has the same discount rate. It would thus have no need to levy any form of tax were it not for a simple need for revenue. We consider various relaxations of this assumption in Section IV.

\section{Cash-flow rent taxation}

Suppose now we introduce profit-based taxes whose purpose is to divert rents to the government. We begin with a classic cash-flow or Brown (1948) tax whose base includes all real cash flows, which in the basic model are $-I$ in period 0 and $p_{t} q_{t}-C\left(q_{t}, S_{t}\right)$ in periods $t \geq 1$. Positive and negative tax liabilities are treated symmetrically by full refundability of negative taxes. If the tax rate $\tau$ is constant across all periods, the value function in period $t$ may be written:

$$
V_{t}\left(S_{t}, \tau\right)=\max _{\left\{q_{t}\right\}}\left\{\left(p_{t} q_{t}-C\left(q_{t}, S_{t}\right)\right)(1-\tau)+\frac{1}{1+r} E_{t}\left[V_{t+1}\left(S_{t+1}, \tau\right)\right]\right\}
$$

and (2) and (3) become:

$$
\begin{array}{r}
\left(p_{t}-C_{q}(t)\right)(1-\tau)=\frac{1}{1+r} E_{t}\left[V_{S}(t+1)\right] \\
V_{S}(t)=-C_{S}(t)(1-\tau)+\frac{1}{1+r} E_{t}\left[V_{S}(t+1)\right]
\end{array}
$$

Following the same procedure as above, we obtain the optimal extraction condition (4). So, the extraction decision is not distorted.

The investment decision is determined by maximizing the analogue of (5):

$$
V_{0}=\max _{\{I\}}\left\{-I(1-\tau)+\frac{1}{1+r} E_{0}\left[V_{1}\left(S_{1}, \tau\right)\right]\right\}
$$

where in period 1 , once information is revealed,

$$
V_{1}\left(S_{1}, \tau\right)=\max _{\left\{q_{1}\right\}}\left\{\left(p_{1} q_{1}-C\left(q_{1}, S_{1}\right)\right)(1-\tau)+\frac{1}{1+r} E_{1}\left[V_{2}\left(S_{2}, \tau\right)\right]\right\}
$$


By recursive substitution, $V_{1}\left(S_{1}, \tau\right)$ is reduced by $(1-\tau)$ since all components $p_{t} q_{t}-$ $C\left(q_{t}, S_{t}\right)$ are reduced (in expectations) by $(1-\tau)$, and

$$
\lim _{t \rightarrow \infty}\left\{\left(\frac{1}{1+r}\right)^{t} E_{t}\left[V_{t+1}\left(S_{t+1}, \tau\right)\right]\right\}=0 .
$$

This means the investment decision is also unaffected by the cash-flow tax.

These results immediately imply that $V_{t}\left(S_{t}, \tau\right)=(1-\tau) V_{t}\left(S_{t}, 0\right)$, so that the cash-flow tax simply reduces the value of the firm by the factor $1-\tau$. Thus shutdown will occur exactly when $V_{t}\left(S_{t}, 0\right)<0$, so that this decision too is undistorted: shutdown will occur if and only if it would also have occurred in the absence of the tax. Moreover, since the extraction path is also the same as in the no tax case, it will take place at exactly the same date.

The above cash-flow tax corresponds to what the Meade Report (1978) called an R-based corporate tax, since it includes only real cash flows in the base. The Report suggested an alternative R+F- base tax which includes both real and financial cash flows, or its equivalent S-base tax whose base included all cash flows to and from shareholders. As long as credit markets are competitive, there are no rents associated with financial cash flows, so taxing them yields no net revenue in present value terms. It may be the case that financial institutions do earn some rents on their transactions, for example, monopoly rents or 'too big to fail' implicit subsidies in the case of large and/or systemically important firms. Taxing their financial cash flows would generate some tax revenue in an efficient way. Since our main concern is with resource firms, however, we leave this aside; consequently, a tax on real cash flows is sufficient to capture resource rents.

Some assumptions are important and worth reiterating. That of a constant tax rate is critical. If the tax rate varies across periods, firms have an incentive to reduce their cash flows in high tax periods (Sandmo 1979; Bond and Devereux 1995). For example, if the per period tax rate increases with the tax base, as a type of progressivity, firms will have an incentive to smooth their cash flows. It is possible in principle to have a progressive cash-flow tax based on cumulative cash flows, administered for example by a system of tax averaging over periods - and indeed many countries attempt to build in some element of progressivity (albeit often imperfectly, as noted later). Arguments for progressive rent taxation raise other issues, notably in relation to attitudes to risk aversion; this is taken up later. It should be stressed too that the efficiency of the cash-flow tax depends critically on the willingness of the government to refund tax losses fully. In practice, governments are often reluctant to do so; Norway is perhaps alone in fully refunding exploration losses. Fortunately, there are feasible alternatives that are equivalent to the cash-flow tax, but avoid the need for full refundability, and are only moderately more difficult to administer. They all share the property that the present value of their tax base is the same as the present value of cash flows. We consider two variants in what follows, one of which is inspired by the corporate tax literature and has 
been recommended by some corporate tax reform proponents (Institute for Fiscal Studies 1991; Mirrlees et. al. 2011), while the other has been advocated explicitly for natural resource taxation and occasionally implemented [Garnaut and Clunies-Ross 1983; Australian Treasury (Henry Report) 2010].

\section{ACE-type rent taxation}

The first variant forms the basis of the Allowance for Corporate Equity (ACE) tax, proposed by the IFS Capital Taxes Group (1991), and now in place, notably, in Belgium and Italy. ${ }^{7}$ The ACE - a form of corporate tax under which firms deduct not only interest paid (as under the standard corporate tax) but an imputed return to equity-is a particular instance of a wider class of non-distorting corporate taxes identified by Boadway and Bruce (1984) in a model with certainty and extended to a setting of uncertainty by Bond and Devereux (1995). This generalized ACE-type tax allows only a proportion of expenditures $(I, C(t))$ to be deducted as they are incurred. Those that are not deducted are carried forward and allowed both a future 'depreciation' deduction and an interest-cost deduction. In effect, this allows unused deductions to be carried forward with interest. The ACE tax can be designed to correspond with a cash-flow tax that takes no account of financial transactions, or it can incorporate them analogously to an S-base tax. Consider the former first.

In terms of the above model of the resource firm, let $A_{t}$ be the value in period $t$ of the sum of past unused deductions. In period $t$, a proportion $\alpha_{t}$ of $A_{t}$ can be written off, and an interest deduction of $r A_{t}$ is also given. The time-path of the book value of unused deductions follows $A_{t+1}-A_{t}=C(t)-\alpha_{t} A_{t}$, where $C(t) \equiv C\left(q_{t}, S_{t}\right)$ as above. At $t=0$, assume for simplicity that $A_{0}=I$, although it would be possible to allow a proportion of initial investments to be written off in period zero without affecting our results. If the firm is wound up in period $T$, all unused deductions are made available through a refundable tax credit.

In the absence of political risk - that is, of future politicians reneging on the crediting of unused deductions - the flow of future tax deductions from current expenditures is perfectly certain. Even though future expenditures are themselves uncertain, once they are incurred, the stream of subsequent deductions is known with certainty. Their value to the firm is therefore their present value discounted at the risk-free interest rate $r$. From the point of view of analyzing the firm's behavior, it is useful to take advantage of this in the following way. We can define the effective cost to the firm of a unit of expenditures in period $t$ as unity less the present value in period $t$ of the tax savings from all future tax deductions. Thus, consider the effective cost to the firm of expenditures $C(t)$ in period $t$. Let $a_{s}$ be the book value of unused deductions that this gives rise to at time $s$, for $s>t$, so $a_{s+1}-a_{s}=-\alpha_{s} a_{s}$, with

\footnotetext{
${ }^{7}$ For more on the ACE, in theory and practice, see Klemm (2007) and de Mooij (2012).
} 
$a_{t}=C(t)$. This results in the following present value of tax deductions from period $t$ expenditures:

$$
\sum_{s=t}^{\infty} \frac{\left(\alpha_{s}+r\right) a_{s}}{(1+r)^{s+1-t}}=\sum_{s=t}^{\infty} \frac{\left(-a_{s+1}+(1+r) a_{s}\right)}{(1+r)^{s+1-t}}=\sum_{s=t}^{\infty} \frac{a_{s}}{(1+r)^{s-t}}-\sum_{s=t}^{\infty} \frac{a_{s+1}}{(1+r)^{s+1-t}}=a_{t}
$$

Thus, the present value of future tax deductions on the expenditure $C(t)$ will be simply $a_{t}=C(t)$, and $\tau C(t)$ will be the present value of tax savings. Therefore, the effective cost of period-t expenditures is $(1-\tau) C(t)$. The same applies for expenditures in all periods (and for the initial investment $I$ if $\alpha_{0}<1$ ). That being the case, and given that revenues are taxed on a cash-flow basis, the tax is effectively equivalent to a cash-flow tax except that the time profile of tax liabilities is moved forward. Real decisions are not affected.

Note the important point that the stream of costs $C(t)$ that will be subject to this ACE treatment can be stochastic. Nonetheless, the ACE is still neutral. The firm knows that whatever $C(t)$ turns out to be in some future period $t$, it will receive, for sure, deductions that in present value exactly equal those costs-so long as there is no political risk and the rate at which unused deductions are carried forward is the same as the risk-free discount rate of the firm.

As Bond and Devereux (2003) show, actual interest deductions can be allowed under an ACE tax, paralleling the case of an $\mathrm{R}+\mathrm{F}$ base, provided they are taxed in the hand of creditors at the same rate. Neutrality requires in this case that, while a proportion $\alpha_{t}$ of unused deduction $A_{t}$ can be written off in period $t$, the ACE risk-free interest deduction is applied only to $A_{t}$ less the stock of outstanding debt. The tax remains equivalent to a tax on rents because all rents accrue to shareholders as long as bond markets are competitive and generate no rents.

Part of the simplicity of the ACE base is attributable to the fact that the value $\alpha_{t}$ can be chosen at will. It need not reflect actual depreciation or depletion of resources, and can vary from period to period. In particular, it could be chosen such that the government does not incur a negative tax payment in any period. In practice, the ACE tax could choose $\alpha_{t}$ to be constant, except to the extent that negative tax liabilities would be generated. Indeed, one could mimic a cash-flow tax by setting $\alpha_{t}=1$, except that negative tax liabilities would be carried forward with interest (a variant sometimes know as the 'Brown tax' ${ }^{8}$ ). The Mirrlees Review (2011) proposed the ACE for the UK, although it would apply much more broadly than to resource firms. Of course, any of the rent-based taxes discussed here could apply to all industries in the economy, although rents are of more relevance in natural resources than elsewhere.

\footnotetext{
${ }^{8}$ Following Brown (1948).
} 
Similar caveats apply to the ACE tax as to the cash-flow version of the rent tax discussed above. Full efficiency requires that initial expenditures be eligible for ACE deductions regardless of whether they lead to successful discoveries. As noted, this can be a challenge if exploration is done by different firms from those developing and extracting the resource. In effect, unused deductions would have to be refundable for firms that go out of business, or passed on to the firms that acquire resource properties from those who discover them. By the same token, for any resource firm that winds up operations, any unused deductions must be immediately expensed and the tax credit refunded. The tax rate must be constant to maintain efficiency, and political risk must be absent. Governments must be able to commit to maintain constant tax rates. If there is political risk, Bond and Devereux (2003) suggest that the interest rate that the government applies to unused deductions should be sufficiently above the risk-free rate to compensate for the risk that the firm may not be able to deduct them in the future.

\section{RRT-type rent taxation}

An alternative form of rent-equivalent taxation is the Resource Rent Tax (RRT) originally proposed by Garnaut and Clunies-Ross $(1975,1983)$ and since implemented in the Australian mining sector on the recommendation of the Henry Report (2010). Rather than postponing the deductions the firms can make for costs, these schemes postpone when cash flows are brought into the tax base. In the standard version RRT of Garnaut and Clunies-Ross, firms postpone all cash flows from taxation until some threshold rate of return has been reached, that is, until cash flows cumulated by the threshold rate of return become positive. This is a special case of the general form of the scheme that we treat here.

Let $F_{t}$ be the value of untaxed cash flows cumulated at the risk-free interest rate $r$ up to period $t$. Suppose $\varphi_{t}$ is the proportion of cumulated cash flows that are added to the tax base in period $t$, so the tax base at $t$ is $\varphi_{t} F_{t}$. The value of $F_{t}$ evolves according to $F_{t+1}-F_{t}=$ $p_{t} q_{t}-C_{t}-\varphi_{t} F_{t}+r F_{t}$. In period $t=0, F_{0}=-I$ (assuming $\varphi_{0}=0$ for simplicity). The tax rate $\tau$ applies to the tax base $\varphi_{t} F_{t}$ in period $t$.

The same argument applies here as in the ACE case above. Consider the cash flow in a particular period, say $t$. Even though the cash flow $p_{t} q_{t}-C_{t}$ is stochastic, once it is realized, the present value of the future taxes paid on that cash flow is known with certainty. Specifically, let $f_{s}$ be the cumulated untaxed cash flow in periods $s \geq t$ resulting from the cash flow $p_{t} q_{t}-C_{t}$. This evolves according to $f_{s+1}-f_{s}=-\varphi_{s} f_{s}+r f_{s}$, with $f_{t}=p_{t} q_{t}$ $C_{t}$, and gives rise to an addition to the tax base in period $s$ of $\varphi_{s} f_{s}$. This results in the following present value of additions to the tax base resulting from $f_{t}$ :

$$
\sum_{s=t}^{\infty} \frac{\varphi_{s} f_{s}}{(1+r)^{s+1-t}}=\sum_{s=t}^{\infty} \frac{(1+r) f_{s}-f_{s+1}}{(1+r)^{s+1-t}}=\sum_{s=t}^{\infty} \frac{f_{s}}{(1+r)^{s-t}}-\sum_{s=t}^{\infty} \frac{f_{s+1}}{(1+r)^{s+1-t}}=f_{t}
$$


Therefore, since $f_{t}=p_{t} q_{t}-C_{t}$, the present value of tax liabilities arising from the cash flow of $p_{t} q_{t}-C_{t}$ is just $\tau\left(p_{t} q_{t}-C_{t}\right)$ which is equivalent to the cash-flow tax. The same principle applies to cash flows in every period, so the RRT-type tax is equivalent to a cash-flow tax.

Since the tax uses cash accounting, it is readily administered, provided firms report their cash flows truthfully to the tax authorities. The only additional piece of information compared with a cash-flow tax is the interest rate $r$, referred to as the uplift or threshold rate, which in the absence of political risk should, in order to ensure neutrality, be the risk-free interest rate. $^{9}$

The equivalence applies for any time profile of $\varphi_{t}$, and as above this can be chosen to avoid negative tax liabilities. The cash-flow tax is a special case where $\varphi_{t}=1$ for all $t$. The RRT of Garnaut and Clunies-Ross, or the Henry Report, sets $\varphi_{t}=0$ for $F_{t}<0$ and $\varphi_{t}=1$ otherwise. ${ }^{10}$ Of course, when $F_{t}$ reaches zero may be uncertain, but that does not affect the neutrality of the scheme. As with the ACE and cash-flow versions of rent taxation, it is important that the initial investment be treated on an RRT basis. This includes the case where projects are aborted after the initial expenditures are incurred.

One further point should be noted. While the cash flow tax, Brown tax and members of the ACE and RTT families of taxes are equivalent in present value, they imply quite different time paths of revenue to the government and net receipts to the firm. While there is nothing in the modeling here to capture a distinct preference over such paths, in practice, this does often appear to be a significant consideration.

\section{Profit taxes in practice}

The message from the preceding analysis is that it is feasible to design rent taxes that capture a share of the rents from resource-producing firms in an efficient way. Yet, when profit taxes are applied to resource firms, they typically deviate significantly from rent taxes. Losses are commonly neither refundable nor carried forward with interest. The base often closely mimics corporate tax design, so interest is deductible but not the cost of equity finance. As

\footnotetext{
${ }^{9}$ In the RRT proposed by Garnaut and Clunies-Ross (1975), the threshold rate of return is the supply price of funds to the firm, which incorporates risk and varies from firm to firm. In the model we present here, the uplift rate is the risk-free rate of interest for the same reason as in the ACE-type tax discussed above.

${ }^{10}$ Some countries impose taxes along these lines that are 'progressive' in the sense that additional tax is applied when cumulative new flows calculated at some higher uplift rate become positive. Such taxes are distorting, however, since incurring costs today becomes more attractive than it otherwise would be if —as it generally will, the aim being to impose additional tax on especially high return projects - the uplift rate exceeds the riskfree return (since the future reduction of tax then has positive present value)—behavior known in the industry as 'gold-plating.'
} 
well, deductions for exploration, development and depletion are often inappropriate. Where rent taxes are applied, cash-flow or RRT systems may be used, but usually imperfectly; several countries, for instance, apply 'R-factor' taxes which impose liability only when cumulative revenues exceed cumulative costs, but without carrying forward these amounts with interest and so make no allowance for the time value of money. Unsuccessful firms in many cases obtain no relief for their negative cash flows, and for successful firms, the uplift rate under RRT-type systems typically exceeds the risk-free interest rate.

More generally, governments often deploy other policy instruments to obtain a return on resources, often in combination with profit taxes. Some such policies do not detract from efficiency, such as auctions. To the extent that they are competitive, auctions ought to capture rents as efficiently as rent taxes (Klemperer 2004; Cramton 2007). Since auctions occur before resource production commences, their yield will be reduced to the extent of expected future tax liabilities. ${ }^{11}$ Moreover, the inefficiencies of subsequent tax policies undo the efficiency of auctions. Other policies, such as royalties, are themselves inefficient as the next section shows. The end result is that actual resource tax regimes deviate considerably from the rent tax ideal discussed above. ${ }^{12}$

A natural question is why governments choose to implement regimes with multiple instruments, especially those that violate the rent tax principle. There may be purely political economy reasons. However, as we discuss in more detail in a later section, it might be quite rational for the government to deviate from rent taxation if the assumptions of the above model do not apply.

We return to that after we have considered royalties, the other main form of resource taxation.

\section{Royalties}

\section{A. Preliminaries}

Despite the apparent appeal of a rent tax as an instrument for obtaining a fair share of the return on natural resources, governments often deploy royalties either instead of or alongside

\footnotetext{
${ }^{11}$ Some evidence of this is presented in Busby, Dachis, and Dahlby (2011). They estimate that oil and gas royalty rate increases in Alberta in 2007 were almost entirely offset by reductions in auction values for new leases, so government revenue was unchanged.

${ }^{12}$ Mintz and Chen (2012) calculated marginal effective tax rates (METRs) for oil and gas industries in Australia, Brazil, Norway, and the United Kingdom, as well as several provinces in Canada and states in the USA. They found sizable positive METRs in almost all cases, especially when both resource taxes and corporate income taxes were included.
} 
rent taxes. Why that is so is something we return to later. Here we focus on the efficiency properties of royalties.

Royalties can take various forms, but their general feature is that they are based on the amount of resource extracted each period, in terms of either value or quantity. As the term implies, a royalty is a payment to the government for the use of a publicly owned resource. Being a mandatory payment to the government, it has the characteristics of an excise tax on production, but it is often regarded as a user charge or fee rather than a tax by policy-makers, legal authorities and in the government's accounts. Two main features distinguish a royalty from an ordinary excise tax. One is that it is payment for the right to use a resource, so is in that somewhat legalistic sense like the purchase of a factor of production [as discussed in Conrad, Hool and Nekipelov (2009)]. The second is that the payment of royalties on resource extraction is often accompanied by contractual rights to exploit a resource, which are almost always of limited duration. Moreover this right may have been acquired through a bidding process in which case at least part of the benefit is already reflected in the license payment.

To begin with, we set aside these special institutional features of royalties and treat them simply as a payment to the government for the right to extract a resource for an indefinite period. Later we address some of the issues that arise when resource extraction is constrained by contractual agreement between producers and the government. The simple model of the previous section provides a convenient setting for examining the design and effects of royalties.

\section{B. Royalties and inefficiency}

Let the royalty per unit of resource output be $\theta_{t}$, which we allow to vary across periods. Then, under a pure royalty scheme, after-tax cash flow in period $t$ is $\left(p_{t}-\theta_{t}\right) q_{t}-C(t)$, where $C(t) \equiv C\left(q_{t}, S_{t}\right)$ as before. In period zero, cash flow is still $-I$. Eqs. (1) and (2) become:

$$
\begin{aligned}
V_{t}\left(S_{t}, \theta_{t}\right)= & \max _{\left\{q_{t}\right\}}\left\{\left(p_{t}-\theta_{t}\right) q_{t}-C\left(q_{t}, S_{t}\right)+\frac{1}{1+r} E_{t}\left[V_{t+1}\left(S_{t+1}, \theta_{t+1}\right)\right]\right\} \\
& p_{t}-C_{q}(t)-\theta_{t}=\frac{1}{1+r} E_{t}\left[V_{S}(t+1)\right]
\end{aligned}
$$

Equation (3) remains unchanged. Proceeding as above, we can eliminate the terms in $V_{S}(\cdot)$ and obtain the analogue of (4):

$$
\frac{E_{t}\left[p_{t+1}-C_{q}(t+1)-\theta_{t+1}\right]-\left(p_{t}-C_{q}(t)-\theta_{t}\right)}{p_{t}-C_{q}(t)-\theta_{t}}=r+\frac{E_{t}\left[C_{S}(t+1)\right]}{p_{t}-C_{q}(t)-\theta_{t}} .
$$


Two problems are apparent from the above expressions. First, while it is possible for the royalties $\theta_{t}$ to be chosen such that condition (4) determining the optimal path of extraction is satisfied, the optimal royalty would be difficult to implement. The optimal values of $\theta_{t}$ would vary from firm to firm, they would be stochastic, and they would be complicated. For example, consider the simplest case where there are no costs of extraction, so (14) reduces to

$$
\frac{E_{t}\left[p_{t+1}-\theta_{t+1}\right]-\left(p_{t}-\theta_{t}\right)}{p_{t}-\theta_{t}}=r
$$

If there were no uncertainty, so $E_{t}\left[p_{t+1}-\theta_{t+1}\right]=p_{t+1}-\theta_{t+1}$, royalty rates would have to increase at the rate of interest to ensure efficient extraction: if they did not, the present value of revenue, and hence (given the assumed absence of extraction costs) profits, could be increased by either accelerating or deferring extraction. (If, for instance, the royalty is constant over time, so that $\theta_{t}=\theta_{t+1}$, then the firm can reduce its present value tax bill by delaying extraction from $t$ to $t+1$.) With uncertainty, the expected royalty rate would have to rise at the interest rate to ensure optimal extraction, and actual royalties each period would be contingent on the information available at that time.

The second apparent problem is that if royalties distort the extraction path, they will also tend to distort the shutdown decision. To see this, denote the value of the firm at time $t$ by $V_{t}\left(S_{t}, \theta_{t} \mid \theta_{t+1}, \cdots\right)$, making explicit the dependence of the $V_{t}$ on the (expected) future path of royalties. If royalties are distortionary, $V_{t}\left(S_{t}, \theta_{t} \mid \theta_{t+1}, \cdots\right)<V_{t}\left(S_{t}, 0 \mid 0, \cdots\right)-T$, where $V_{t}\left(S_{t}, 0 \mid 0, \cdots\right)$ is the value of the firm at time $t$ in the absence of royalties and $T$ is the expected present value of future royalty revenues, with the inequality reflecting the deadweight loss of the royalty scheme. The firm will shut down in the first period in which its value becomes negative. Suppose that $T>0$ when $V_{t}\left(S_{t}, \theta_{t} \mid \theta_{t+1}, \cdots\right)=0$, that is, royalties do not fall to zero in present value at shutdown. Then, $V_{t}\left(S_{t}, 0 \mid 0, \cdots\right)>0$, so it would have been socially optimal for the firm to stay in business. In this sense, the firm shuts down too soon. This does not mean the extraction will stop at an earlier calendar date than it would have in the absence of taxation: as noted in the previous paragraph, a constant royalty might lead to a flatter extraction profile that, in itself, tends to lengthen the production period. The point, rather, is that continuation would have been socially preferable. ${ }^{13}$

A further problem with royalties arises because they apply only to production and leave initial exploration and development expenditures untouched. The implications of this can be seen by considering again the investment decision in period zero, which, allowing for the royalty, is now given by the solution to:

\footnotetext{
${ }^{13}$ This does not mean the extraction will stop sooner than it would have in the absence of taxation: as noted in the previous paragraph, a constant royalty might lead to a flatter extraction profile that, in itself, tends to lengthen the production period.
} 


$$
V_{0}=\max _{\{I\}}\left\{-I+\frac{1}{1+r} E_{0}\left[V_{1}\left(S_{1}, \theta_{1}\right)\right]\right\}
$$

where in period 1 ,

$$
V_{1}\left(S_{1}, \theta_{1}\right)=\max _{\left\{q_{1}\right\}}\left\{\left(p_{1}-\theta_{1}\right) q_{1}-C\left(q_{1}, S_{1}\right)+\frac{1}{1+r} E_{1}\left[V_{2}\left(S_{2}, \theta_{2}\right)\right]\right\} .
$$

Substituting recursively, the valuations in all periods during which extraction occurs are reduced by the royalty payment. Since the firm's optimal investment decision satisfies:

$$
\frac{1}{1+r} E_{0}\left[V_{S}(1)\right] \bar{S}^{\prime}(I)=1
$$

and, using a recursive argument similar to that after (11), the marginal value of resource deposit $V_{S}(1)$ on the left hand side has been reduced by the royalty, investment has been discouraged. This can be seen more explicitly for the case considered above where extraction costs are independent of $S_{t}$. Combining (3) and (13), we obtain for period 1:

$$
V\left(S_{1}, \theta_{1}\right)=\left(p_{1}-C_{q}(1)-\theta_{1}\right) S_{1}
$$

Therefore, $V_{S}(1)=p_{1}-C_{q}(1)-\theta_{1}$, so the optimal investment condition becomes:

$$
\frac{1}{1+r} E_{0}\left[p_{1}-C_{q}(1)-\theta_{1}\right] \bar{S}^{\prime}(1)=1
$$

Comparing this with (6), the disincentive to invest is clear.

The efficiency of investment in the presence of royalties could be restored by subsidizing investment [cf., Daubanes-Lasserre (2011)]. But that might be small consolation given the virtual impossibility of designing the royalty to achieve efficient extraction, and the fact that the shutdown decision is accelerated.

One artificial way to make the royalty scheme neutral with respect to the extraction decision would be to define it in ad valorem terms, and to let extraction costs be deducted. Denote the ad valorem royalty rate by $\sigma$, and let it apply to the base $\left(p_{t}-c\left(q_{t}, S_{t}\right)\right) q_{t}$ in period $t$, where $c\left(q_{t}, S_{t}\right)$ is per unit costs of extraction in period $t$, defined as $c\left(q_{t}, S_{t}\right) \equiv C\left(q_{t}, S_{t}\right) / q_{t}$. Then the equivalent per unit royalty rate in period $t$ applying to extraction $q_{t}$ is given by $\theta_{t}=$ $\sigma\left(p_{t}-c\left(q_{t}, S_{t}\right)\right)$, so the after-tax cash flow in period $t$ is $(1-\sigma)\left(p_{t}-c\left(q_{t}, S_{t}\right)\right) q_{t}$. This is 
obviously neutral with respect to the extraction decision, and is effectively a cash-flow tax on extractions. ${ }^{14}$ Given that, the shutdown decision is undistorted. For full neutrality, initial investment would have to be deductible from the royalty base, which then turns the royalty into a full cash-flow tax.

It is clear then that unless royalties are artificially designed to mimic a cash-flow rent tax, they will impose distortions on resource production. They will result in an inefficient rate of extraction, induce firms to shut down production too soon, and discourage exploration. In effect, royalties impose a tax on quasi-rents (meaning rents earned ignoring sunk costs of exploration and development), and an inefficient one at that. These effects can readily be seen in the typical royalty scheme whose rate is fixed over time (apart from occasional discretionary changes that we discuss further below). Firms will then generally be induced to extract too slowly. Since the royalty rate remains positive as long as extraction occurs, the firm will be induced to shutdown too soon since the cost of producing the resources include both extraction costs and the royalty. And, exploration and development will be discouraged since initial investments are not deductible.

In a more complicated setting than above, there may be other inefficiencies induced by royalties. One occurs when a resource deposit is heterogeneous and contains components of different quality. If the royalty is based on production volumes, it will be relatively less burdensome for higher quality components, thus encouraging preferential extraction of these components (known as 'high-grading'). ${ }^{15}$

On the other hand, for some resource types, firms may have relatively little discretion over extraction period by period. In the case of petroluems, in particular, extraction possibilities are largely dictated by the pressure of the well. Royalties then no longer affect the rate of extraction, removing that source of inefficiency. However, they continue to affect the incentive to invest in exploration and development as well as the shutdown decision. They may also affect the rate of extraction indirectly; as Smith (2012b) elaborates in the petroleum context, the lower initial investment to which royalties leads may mean a smaller loss of reservoir pressure as production begins, and hence tend to cause extraction to fall less rapidly (and possibly later abandonment).

\footnotetext{
${ }^{14}$ In a similar vein, Conrad, Hool, and Nekipelov (2009) show how an optimal royalty scheme can be obtained as an optimal payment mechanism in a principal-agent relationship between the government (the resource owner) and the resource producer.

${ }^{15}$ For a detailed analysis of the effect of resource royalties when resource properties are heterogeneous, see Conrad and Hool (1981).
} 


\section{Complications}

In the previous sections, the firm shared the same objective as the government, so there was no market failure. Decentralizing the government's preferred exploration, development and extraction profile, while transferring revenue to itself, was then seen to be conceptually straightforward: we saw how the government could extract revenues from the producing firms using an appropriately designed rent tax, but that this would be practically impossible using royalties as conventionally defined. Yet, as mentioned, royalties are commonly used in practice, and taxes explicitly intended to capture rents are often absent (remaining rare, most notably, in mining) or imperfect. In this section, we explore some considerations-resting on asymmetries in the preferences and information sets of government and firm - that might help explain these observations. We do not attempt a full explanation (which would also require delving into political economy issues). Nonetheless, the explanations we pursue provide some insight into the nuances involved in actual resource tax design.

\section{A. Divergences between public and private valuations of resource stocks}

There are several possible reasons why the firm's valuation of resource stocks, $V(S)$, might differ from that of the government, which we now denote by $\Phi(S)$.

\section{Differences between public and private discount rates}

We assumed above that the government's discount rate was, like the resource firm owner's, the risk-free interest rate. This is the interest rate at which agents in the economy discount present versus future consumption, and as long as the economy operates efficiently, one might argue that the government should use the same rate. However, resource properties are long-lived and the rents accruing on them span several generations of households. The government's discount rate should reflect the relative weight put on the consumption of those generations. It might be argued that the market interest rate already incorporates intergenerational considerations since some saving is for bequests and presumably reflects how present generations weigh the consumption of future generations. But it seems likely that the welfare of future generations is not adequately weighted in market interest rates. For one thing, even if current generations are motivated by altruism, that is not fully captured in the capital market because of the public good nature of saving for future generations. For another, to the extent that the interest rate does capture altruism, the weight given to future generations is based only on what current generations prefer, not on an intergenerational social welfare function that weights all generations equally.

In the case of natural resources and other public assets, there is a strong ethical argument for taking the view that the benefits of public ownership should be shared across all subsequent generations, regardless of when the resource is extracted. This is the position taken, for example, by Ramsey (1928) and more recently in the Stern Review on the economics of climate change (Stern 2007), where the public asset is the quality of the environment. In 
general, and in a risk-free world, the social discount rate, that is the rate at which consumption should be discounted, takes the simple form,

$$
\rho=\delta+\varepsilon \cdot g
$$

where $\delta$ is the pure time preference rate (the rate at which intergenerational utility is discounted, which, in the Stern view of the world, may be close to zero), $\varepsilon$ is the elasticity of the marginal utility of consumption and $g$ is the rate of growth of consumption. ${ }^{16}$ The comparable expression in a world of uncertainty is more complicated. In a simple two-period model with constant relative risk aversion $\varepsilon$, the risk adjusted social discount rate can be written: ${ }^{17}$

$$
\rho=\delta+\varepsilon \cdot E[g]-\operatorname{cov}\left[u^{\prime}\left(c_{2}\right), \Delta c_{2}\right]
$$

There is no reason to suppose that the social discount rate for public assets $\rho$ equals the market interest rate $r$. That being the case, the outcome of resource production decisions made by private firms exploiting a publicly owned resource is likely to be socially inefficient. This leads to the possibility of a corrective role for government policy. If $\rho<r$, firms will tend to extract the resource faster than is optimal for the government; that is, the firms sees relatively less benefit from postponing extraction. The government could discourage extraction by a royalty that falls in present value over time (and vice versa if $\rho>r) .{ }^{18}$ As well, if $\rho<r$, by (6) the firm will tend to under-invest in exploration and development. An investment subsidy or negative royalty will serve to encourage investment. By the same token, under a rent tax regime, investment can be encouraged by increasing the uplift rate. However, this would have to be accompanied by a falling royalty to reduce the extraction rate.

Differences in the discount rate will also imply that the government and the firm evaluate the present value of the stream of revenues differently. Suppose that $\rho>r$. The government will put a premium on tax revenues being paid sooner relative to the firm. In principle, an implicit

\footnotetext{
${ }^{16}$ To see this most simply, suppose utility is given by $u(c)=c^{1-\varepsilon} /(1-\varepsilon)$. The discount factor applied to consumption at time $t$ relative to the present is $\mu=e^{-\delta t} u^{\prime}(c)=e^{-\delta t} c^{-\varepsilon}$. The discount rate is then $\dot{\mu} / \mu=\delta+$ $\varepsilon \cdot g$, where $g=\dot{c} / c$ and the dot indicates a time derivative. The same relation holds for more general preferences as a first-order approximation.

${ }^{17}$ Consider an amount $a$ of an asset with a price $p$ yielding a stochastic return $x$ next period. Expected utility to the government is $u\left(y_{1}-a p\right)+E\left[u\left(y_{2}+a x\right)\right] /(1+\delta)$, where $y_{i}$ is exogenous income in period $i$. From the first-order condition on the choice of $a$, we can derive $p=E[x] /\left(1+\delta+\varepsilon E[g]-\operatorname{cov}\left[u^{\prime}\left(c_{2}\right), \Delta c_{2}\right]\right)$.

${ }^{18}$ More precisely, replacing $r$ in (4) by $\rho$, comparison with (14) implies (assuming for simplicity that $C_{S}=0$ ) a path of royalties such that

$$
\theta_{t}-\frac{\theta_{t+1}}{1+r}=\frac{r-\rho}{1+r}
$$
}


intertemporal trade of tax revenues could be beneficial for both the government and the firm. Thus, relative to a rent tax regime, both the firm and the government could benefit by reducing the rate of rent tax and instituting an auction system for leases: the amount that the firms would be willing to bid for the leases would more than offset the present value of the loss of future rent taxes by the government.

\section{Fine contract periods}

An extreme case of differences in intertemporal trade-offs occurs when the lease contract between the firm and the government is of limited duration relative to the life of the resource stock. In these circumstances, there is an incentive for the firm to extract the resource too rapidly. In terms of our earlier schematic model of a resource firm, the extraction condition (2) will not fully apply since the firm will put no weight on the value of resources remaining at the end of the contract period, so will tend to underestimate (and may even entirely neglect) the Hotelling rent, a point analyzed and stressed in particular by Conrad, Hool, and Nekipelov (2009). ${ }^{19}$

To see this, and its implications, consider the problem faced by a firm whose right to extract the resource will terminate at the end of period $T$. Then, since it receives no value from resources then left unextracted, $V_{T+1}\left(S_{T+1}, \theta_{T+1}\right)=0$, and, recalling (12), its problem in period $T$ becomes simply

$$
V_{T}\left(S_{T}, \theta_{T}\right)=\max _{\left\{q_{T}\right\}}\left\{\left(p_{T}-\theta_{T}\right) q_{T}-C\left(q_{T}, S_{T}\right)\right\} .
$$

Supposing further that extraction costs are independent of the stock, the firm's optimal extraction in period $T$ becomes independent of the stock $S_{T}$ with which it enters the period; and hence the marginal value of that stock, $V_{S}(T)$, is zero. But then the firms' value in the previous period

$$
V_{T-1}\left(S_{T-1}, \theta_{T-1}\right)=\max _{\left\{q_{T}\right\}}\left\{\left(p_{T-1}-\theta_{T-1}\right) q_{T-1}-C\left(q_{T-1}, S_{T-1}\right)+\frac{1}{1+r} E_{T}\left[V_{T}\left(\theta_{T}\right)\right]\right\}
$$

is also independent of the stock. Continuing the recursion, it follows that $V_{S}(t)=0$ in all periods: intuitively, an additional resource discovery would have no value to the firm (so long as it does not in itself affect extraction costs) since it plans, in any event, to leave resources unused at the end of its contract period. Given this, (13) now implies that the firm extracts in each period to the point at which

\footnotetext{
${ }^{19}$ There are also links with the literature on the impact on exploration and extraction of the possibility of expropriation: see for instance Bohn and Deacon (2000).
} 


$$
p_{t}-C_{q}(t)-\theta_{t}=0
$$

and so entirely neglects the scarcity value of resources. This means_-assuming that the socially optimal extraction path has some resources, with value, unexploited at the end of the contract period - that resources tend to be extracted too quickly. Comparing with (2), this distortion can be corrected by setting a path of royalties such that, at each point in the contract period,

$$
\theta_{t}=\frac{1}{1+r} E_{t}\left[\Phi_{S}(t+1)\right]
$$

so that the firm faces a royalty that exactly internalizes the social value of leaving resources in the ground.

Though not explored further here, there are also potential implications for initial investment in exploration. If the firm that undertakes exploration also expects to have a finite lease period for extraction, it will have an incentive to limit its investments so as to reduce the stock that is left underground when the lease expires. To correct this, initial investment would have to be subsidized.

The practical importance of these issues, and, in particular, the case on these grounds for a corrective role for royalties remains unclear. ${ }^{20}$ Most contracts do indeed specify a terminal date, and provide for the possible transfer of extraction rights to another party at that time. In principle, the recursion argument above means that the case for a corrective royalty applies, however long the contract period. It seems likely, however, to be particularly important for shorter contracts, since the likelihood that a socially optimal extraction path leaves some resources in the ground may be greater in such cases. Lease terms are indeed sometimes fairly short: most notably it seems in the United States, where oil lease terms may be three to ten years (a feature perhaps associated with the private ownership of the resource, which is common in the U.S. but rare elsewhere). In many other cases, however, the term is far longer-25 years, for instance, in Libya's model production sharing contract, which is a fairly typical example. Perhaps most germane, however, is the likelihood that an existing lease will be extended, or a payment made to the firm in the event of non-renewal that reflects the value of unextracted resources. On the latter, we know of no examples of such terminal bonuses. On the former, however, incumbents do in practice often seem to have extremely strong chances of renewal, whether because of their inherent advantage or other reasons. The greater the likelihood of renewal, the less one would expect the distortion to be (though of course long contract periods may raise other issues). But all this though remains speculation: there is essentially no empirical evidence on the importance of the issue.

\footnotetext{
${ }^{20}$ The sharp form of the result here relies on the assumption that extraction costs are independent of the remaining stock; relaxing this, the marginal shadow value of the resource to the firm will remain positive until the start of period T; but the essential distortion from the finite lease period remains.
} 


\section{More generally}

Beyond the two just considered, there are many other reasons why private and social valuations of resource stocks might differ: the government might, for example, attach particular value to resource stocks on grounds of national security. The analytical similarity of all such cases points to a broad commonality of response, evident above. This has two elements. The first is the use of a royalty (positive if the social marginal valuation excess the private) to ensure the socially optimal extraction path: setting

$$
\theta_{t}=\frac{1}{1+r} E_{t}\left[\Phi_{S}(t+1)-V_{S}(t+1)\right]
$$

in (3) implies that

$$
p_{t}-C_{q}(t)=\frac{1}{1+r} E_{t}\left[\Phi_{S}(t+1)\right]
$$

so that extraction follows the social optimal path. ${ }^{21}$ The second is the use of a subsidy or equivalent to ensure that, given the corrective royalty, the initial level of investment is also optimal. While thus clear enough in principle, calibrating the appropriate corrections may well be very hard in practice.

\section{B. Differences in risk aversion}

So far we have assumed that both the government and the resource producer are risk-neutral. If one or the other, or both, are risk-averse, opportunities for risk-trading arise, which complicates matters substantially. To illustrate the considerations that arise, it is helpful to consider a setting with one production period and a project of pre-determined size. Suppose the project yields a given quantity of output, normalized to unity, and that the (net-of-cost) price varies according to some probability distribution, known to both the government and the firm. Let $p(s)$ be the price in state $s$, which occurs with probability $\pi(s)$, and suppose the government applies a state-contingent tax $\tau(s)$ to $p(s)$.

This entails that the government obtains state-contingent tax revenues of $\tau(s) p(s)$, leaving $(1-\tau(s)) p(s)$ for the resource firm. The value attached by the government to its revenues

\footnotetext{
${ }^{21}$ Alternatively, the government might of course simply dictate the extraction path to the firm undertaking it. With perfect information, there would be no real difference between this and the royalty-based approach (except of course in the revenue raised). With imperfect information, however, the two approaches are dissimilar for the reasons familiar from Weitzman (1974): under the royalty-based approach for instance, but not under the quantity-based, extraction can respond to price movements. The relative merits of the two approaches in the resource context have not to our knowledge, been explored.
} 
is given by $\sum_{s} \pi(s) u_{G}(\tau(s) p(s))$, and that by the firm is $\sum_{s} \pi(s) u_{F}((1-\tau(s)) p(s))$, where $u_{G}(\cdot)$ and $u_{F}(\cdot)$ are increasing and concave value functions. The government attaches weight both to its own expected value and to that of the firm. Let the relative weight attached to the firm be $\lambda$, so the problem of the government can be written:

$$
\max _{\{\tau(s)\}}\left\{\sum_{s} \pi(s) u_{G}(\tau(s) p(s))+\lambda \sum_{s} \pi(s) u_{F}((1-\tau(s)) p(s))\right\}
$$

(This could also be interpreted as a Pareto-optimizing problem, in which case $\lambda$ is arbitrary.) The first-order condition with respect to $\tau(s)$ is:

$$
u_{G}^{\prime}(\tau(s) p(s))-\lambda u_{F}^{\prime}((1-\tau(s)) p(s))=0 \quad \forall s .
$$

This determines $\tau(s)$ as a function of $p(s)$ and $\lambda$. Differentiating (17) with respect to $\tau(s)$ and $p(s)$, and using (17) to eliminate $\lambda$, we obtain:

$$
\left(\frac{u_{G}^{\prime \prime}}{u_{G}^{\prime}} \tau(s)-\frac{u_{F}^{\prime \prime}}{u_{F}^{\prime}}(1-\tau(s))\right) d p(s)=-\left(\frac{u_{G}^{\prime \prime}}{u_{G}^{\prime}} p(s)+\frac{u_{F}^{\prime \prime}}{u_{F}^{\prime}} p(s)\right) d \tau(s)
$$

This characterizes the properties of the tax function, $\tau(p)$. Letting $\varepsilon_{G}$ and $\varepsilon_{F}$ be the coefficients of relative risk aversion, or equivalently the absolute value of the elasticities of the respective value functions, (so that for instance $\varepsilon_{F}=-U_{G}^{\prime \prime}(1-\tau) p / U_{g}^{\prime}$ ), we obtain, in any given states:

$$
\tau^{\prime}(p)=-\left(\varepsilon_{F}-\varepsilon_{G}\right)\left(\frac{u_{G}^{\prime \prime}}{u_{G}^{\prime}} p^{2}+\frac{u_{F}^{\prime \prime}}{u_{F}^{\prime}} p^{2}\right)^{-1}
$$

Thus, $\tau^{\prime}(p)>0$ if $\varepsilon_{F}>\varepsilon_{G}$, and vice versa. That is, the resource tax should be progressive if and only if the government is less risk-averse than the producer. In the extreme case where the government is risk-neutral, ${ }^{22}$ setting $\varepsilon_{G}=0$ gives $\tau^{\prime}(p)=(1-\tau(p)) / p$. This is equivalent to the condition that $(1-\tau(p)) p$, the net return to the firm, is constant. This could be achieved by the government imposing a 100 percent tax on the firm (i.e., $\tau(p)=1$ ), and giving it a lump-sum transfer, so the government assumes all the risk.

\footnotetext{
${ }^{22}$ This is analogous to the case considered in the next section where social welfare in quasilinear in government revenue.
} 


\section{Asymmetric information}

Asymmetric information is a feature of all tax systems. The tax authorities must rely on selfreporting by taxpayers to establish tax liabilities, which-though of course the government has an opportunity to audit those reports - puts firms in a position of informational advantage. This asymmetry is particularly marked in the resource sector, where many firms are vertically integrated and multinational. Resource firms have ample opportunity to avoid taxes by transfer-pricing, profit-shifting, and the allocation of costs to maximize the value of tax deductions. It is beyond our scope to address general issues of tax avoidance and tax evasion of resource taxation. ${ }^{23}$ However, some features of the nature of asymmetric information between the tax authorities and resource firms have implications for resource tax design, and we consider two examples of that.

\section{Production versus profit information}

The first case arises because of a presumption that production can be monitored by the tax authorities more readily than profits. Large resource firms have some opportunities to book their costs in ways that will attract more favorable tax treatment, by for example incurring them in profitable rather than loss-making affiliates or in high-tax jurisdictions. Those that are inclined to escape taxes may be better able to do so by inflating costs rather than underreporting revenues. Under profit taxation, the over-statement of costs encourages firms to undertake excessive expenditures. Royalties levied on production or revenues preclude the advantage of over-stating costs, and to that extent can be used as an antidote the misreporting profits or cash flows.

The consequences of this can be seen in a much simplified version of our benchmark model. We collapse the model into a two-period setting, where in the first period the firm invests an amount $I$ to generate a stock of resource according to the function $S(I)$, which is increasing and strictly convex. Assume further that all the resource is extracted in period one, so $q=S(I)$, and that the price $p$ and cost of extraction $C(S(I))$ are known with certainty. Adding uncertainty and a multi-period path of extraction add minimal extra insight. The only allocation decision the firm takes is the amount of investment, and that will satisfy the oneperiod analogue of (6). As before, the government can tax rents by deploying a cash-flow tax at the rate $\tau$, and can apply an ad valorem royalty on revenues of $\theta$. In the absence of asymmetric information, the government would choose $\theta=0$, and rely solely on the cashflow tax to raise revenues.

Suppose now that the resource firm can evade or avoid taxes. To keep things simple and deterministic, suppose that the firm is able, by engaging in costly tax planning, to over-report

\footnotetext{
${ }^{23}$ Calder (forthcoming) provides an extensive account of implementation issues in resource taxation.
} 
both its investment and production costs by a multiple $(1+\lambda(\tau))$ without being detected by the tax authorities, where $\lambda^{\prime}(\tau), \lambda^{\prime \prime}(\tau) \geq 0$. The higher the tax rate, the more resources the firm is willing to allocate to hide its true costs. The problem of the firm is to maximize the present value of its after-tax cash flows:

$$
\max _{\left\{q_{t}\right\}} V(0)=-(1-(1+\lambda) \tau) I+\left(\frac{1}{1+r}\right)((1-\theta-\tau) p S(I)-(1-(1+\lambda) \tau) C(S(I)))
$$

From the first-order conditions for this problem, it can be readily seen that investment $I$ is decreasing in the royalty $\theta$ and, for a small enough royalty rate, increasing in the rent tax $\tau$. The two effects will just be offsetting if $\theta$ is set such that

$$
(1-\theta-\tau)=(1-(1+\lambda) \tau)
$$

or $\theta=\lambda \tau>\tau$. In this case, the tax reduces the value of the firm by the proportion ( $1-$ $(1+\lambda) \tau)$, so the mix of royalties and cash-flow taxation is effectively a rent tax, albeit one where there are non-productive costs incurred by the firm to escape detection of its overreporting of costs. Note that the government could choose $\tau$ and $\theta$ sufficiently high to tax away all the rents of the firm, effectively frustrating the benefit to the firm to over-reporting costs.

Of course, being able to choose the combination of royalties and cash-flow taxes such that the two are just offsetting would be an insuperable task in practice. The government would have to know the extent of over-reporting of costs, and that would presumably differ from firm to firm. Moreover, firms will differ in the quality of their resource stocks and so in the cost of extraction. Nonetheless, the intuition of the analysis suggests that there is an a priori case for combining royalties with profit taxation to mitigate the inefficiencies resulting from the relative ease of over-reporting costs relative to under-reporting resource revenues. 


\section{Using contracts to elicit cost information}

Suppose now that the government is simply unable to observe costs, but can observe production or revenues. Suppose also that the government knows that firms are heterogeneous in their costs. Since the government cannot distinguish a high-cost from a low-cost firm, or equivalently a low-rent from a high-rent firm, it cannot use firm-specific policies to extract rents efficiently from the various firms. If, however, the government knew the proportion of firms in the economy that were of different cost characteristics, it could conceivably use multi-dimensional contracts to separate them (Osmundsen 2005 and 2008). In this section, we illustrate this by using a highly stylized version of the standard model. The model we use is a further simplification of the one just discussed. We abstract from period zero by assuming that the stock of resource available to any given firm is fixed and reflected in its cost-of-extraction function. We focus solely on the extraction decision in period 1, and as above, assume prices and costs are known to the firm with certainty. The government, as owner of the resource, contracts with firms for the right to extract. The contract can include a fixed fee $F$ and a royalty of $\theta$ per unit of resource extracted. To make matters as simple as possible, assume there are two types of firms: low-cost firms with the cost function $C_{\ell}(q)$ and high-cost firms with $C_{h}(q)$, where $C_{h}(q)>C_{\ell}(q)$ and $C_{h}^{\prime}(q)>$ $C_{\ell}^{\prime}(q)$. The government knows that there are $n_{i}$ firms of type $i$.

The quasi-rent of a type- $i$ firm is $(p-\theta) q_{i}-C_{i}\left(q_{i}\right)-F$ under policies $\theta$ and $F$. The firm chooses $q_{i}$ to maximize quasi-rents. From the first-order condition $(p-\theta) q_{i}=C_{i}^{\prime}\left(q_{i}\right)$, we obtain the output function $q_{i}(\theta)$, and the profit function $V^{i}(\theta, F)$, where $V_{\theta}^{i}=-q_{i}$ and $V_{F}^{i}=-1$. From the profit function $V_{i}(\theta, F)$, we can derive the marginal rate of substitution between policies for the type-i firm to be:

$$
\left.\frac{d F}{d \theta}\right|_{V^{i}}=-\frac{V_{\theta}^{i}}{V_{F}^{i}}=-q_{i}(\theta) .
$$

Since $q_{\ell}>q_{h}$, this satisfies the single-crossing property required for contracts to be separating.

If the government had full information so it could identify firms by their type, it would maximize the revenue it obtained from each firm by selecting fixed fees $F_{\ell}$ and $F_{h}$ such that $V^{\ell}=V^{h}=0 .{ }^{24}$ But, if the government cannot observe firm types, the full information outcome cannot be implemented. If the government offered contract fees $F_{\ell}$ and $F_{h}$, all firms would choose the contract meant for the high-cost firm since $F_{\ell}>F_{h}$. The best the

\footnotetext{
${ }^{24}$ For each type of firm, the government's problem is to maximize $\theta_{i} q_{i}\left(\theta_{i}\right)+F_{i}$ subject to $V_{\ell} \geq 0$. The solution is $F_{i}>0$ and $\theta_{i}=0$.
} 
government could do using fixed fees would be to offer all firms $F_{h}$, which would at least extract all rents from high-cost firms, but leave low-cost firms with positive rents. However, the government might be able to do better than that by taking advantage of the above singlecrossing property to separate firms. By (18), the reduction in the fee required to compensate type- $h$ firms for a higher royalty rate is less than for type- $\ell$ firms. Thus, a contract offering a reduced fee and increased royalty will be more attractive to high-cost firms.

More formally, suppose the government offers two contracts of the forms $\left(F_{\ell}, \theta_{\ell}\right)$ and $\left(F_{h}, \theta_{h}\right)$ such that each firm will choose the contract intended for its type. (These fees, note, can also be interpreted as rent taxes, levied on the earnings at the allocation intended for each type $i$ at such a rate as to imply a tax payment of $F_{i}$.) The optimal choice of contracts that maximizes government revenue satisfies the following problem:

$$
\max _{\theta_{h}, \theta_{\ell}, F_{h}, F_{\ell}} n_{\ell}\left(\theta_{\ell} q_{\ell}\left(\theta_{\ell}\right)+F_{\ell}\right)+n_{h}\left(\theta_{h} q_{h}\left(\theta_{h}\right)+F_{h}\right)
$$

subject to

$$
\begin{gathered}
\left(p-\theta_{\ell}\right) q_{\ell}\left(\theta_{\ell}\right)-C_{\ell}\left(q_{\ell}\left(\theta_{\ell}\right)\right)-F_{\ell} \geq\left(p-\theta_{h}\right) q_{h}\left(\theta_{h}\right)-C_{\ell}\left(q_{h}\left(\theta_{h}\right)\right)-F_{h} \\
\left(p-\theta_{h}\right) q_{h}\left(\theta_{h}\right)-C_{h}\left(q_{h}\left(\theta_{h}\right)\right)-F_{h} \geq 0 .
\end{gathered}
$$

The first constraint is the incentive constraint that precludes type- $\ell$ firms from choosing the contract of the type- $h$ 's. The second constraint requires that the high-cost firms not make a loss. Both constraints will be binding in an optimum. (No non-negativity constraint is required for the type- $\ell$ 's since they necessarily obtain positive profits.)

The first-order conditions yield the following characterization of the two contracts offered. For the low-cost firms, we obtain $\theta_{\ell}=0$ and $F_{\ell}>0$. That is, the decisions of the low-cost firms are not distorted, which is the standard no-distortion-at-the-top result. Type- $\ell$ firms do however receive positive informational rents. This follows from the fact that the two constraints imply that $\left(p-\theta_{\ell}\right) q_{\ell}-C_{\ell}\left(q_{\ell}\right)-F_{\ell}>C_{h}\left(q_{h}\right)-C_{\ell}\left(q_{h}\right)>0$.

For type- $h$ firms, the zero-profit condition (20) is binding, and the royalty is given by:

$$
\theta_{h}=\frac{n_{\ell}\left(C_{\ell}^{\prime}\left(q_{\ell}\right)-C_{\ell}^{\prime}\left(q_{h}\right)\right)}{n_{\ell}+n_{h}}
$$

Since $q_{\ell}>q_{h}$, the royalty rate is positive. Thus, the output of high-cost firms is distorted downward to deter low-cost firms from taking the contract intended for the high-cost firms. The royalty will be higher, and the lump-sum fee lower, the higher is the share of low-cost firms and the more convex is the cost curve of the low-cost firm. 
This is a rudimentary example that serves only to illustrate the potential for using a mixture of royalties and rent taxes to sort resource firms by their unobservable costs. Extending the example to more than two types of firms is feasible, provided that the government knows the proportions of firms of different types. The result would be a menu of royalties and fees, or more generally a nonlinear royalty structure with the royalty rates decreasing and feesequivalently, tax payments associated with differential rent taxes-increasing in resource output.

Extending the analysis to more than one period poses more of a challenge. In the above twotype example, if production occurred for $T>1$ periods, one option would be for the government to offer multi-period contracts with an upfront fee and per-period royalties, potentially different in each period. Firms would separate into contracts as above. Apart from the complexity of such contracts and the requirement that the government be sufficiently informed about the production technology of each type of firm, there are two key problems. One is that if there is uncertainty about future prices and costs, the contracts would ideally have to be contingent upon future states of the world. The second is that the government would have to be able to commit to abide by the contracts taken up by each firm. Since firms reveal their type in accepting a contract, it is tempting for the government to renege on the contract and exploit the information they have learned about firms to extract more rent. Given the length of life of resource projects, the ability of governments to commit to existing contracts is not a given, especially since new governments replace old ones every few years. We take up this commitment issue further in the next subsection.

The analysis could also be extended backward to pre-production periods. In the one-period model considered above, the stock of the resource was taken as given, so the rents that the fee-cum-royalty policy was intended to tax were quasi-rents. It would be straightforward within the perfect confines of that model to allow for an initial period of investment followed by the production period. Assuming the government could observe neither investment nor production costs, it would still be feasible to set contracts consisting of a fee and a production royalty. The optimal royalty would distort not only the production but also the investment of the high-cost firm.

\section{Commitment}

A salient feature of natural resource production is its duration. Relatively large capital expenditures that result in the discovery and development of resource properties lead to lengthy periods of extraction. Once these capital expenditures have been undertaken, they are largely irreversible and thus constitute sunk costs. It is tempting for the government to impose high taxes on the quasi-rents resulting from these sunk investments - taxes that would constitute a disincentive to invest if they had been anticipated earlier (Osmundsen 2010). In these circumstances, intuition might suggest that the irresistibility of imposing high 
taxes on quasi-rents would be anticipated by resource producers and would discourage them from investing in the first place. That is, if governments cannot commit to future taxes during the extraction phase, firms would rightly expect high taxes and would scale back their investment significantly. In a time-consistent equilibrium, there would be too little initial investment, unless the government was somehow able to offer countervailing investment incentives up-front.

This intuition is not always correct, however. It is well-known from the dynamic policy literature that if the government has sufficient policy instruments to implement the first-best outcome, the inability to commit to future tax rates is inconsequential. (See Hillier and Malcomson 1984; Calvo and Obstfeld 1988.) We begin by adopting our standard model to show that this logic applies to natural resource taxation as well: if the government can deploy a non-distorting rent tax, the time-consistent outcome will be the same as the fullcommitment one.

Assume a three-period full-certainty version of our standard model. In period zero, the firm invests $I$ and generates a stock of a resource $S(I)$, where $S^{\prime}(I)>0>S^{\prime \prime}(I)$. Extractions are $q_{1}$ and $q_{2}$ in periods 1 and 2 , and the extraction cost in period $i$ is $C\left(q_{i}\right)$, which is independent of the stock for simplicity. The resource sells for a price $p_{i}$, and all the resource is extracted over the two periods. The government can impose a tax on rents at the rates $\tau_{0}$, $\tau_{1}$, and $\tau_{2}$ in the three periods. Given full-loss offsetting, the after-tax profit of the firm, using $q_{2}=S(I)-q_{1}$, is

$$
\Pi=-\left(1-\tau_{0}\right) I+\left(1-\tau_{1}\right) \frac{p_{1} q_{1}-C\left(q_{1}\right)}{1+r}+\left(1-\tau_{2}\right) \frac{p_{2}\left(S(I)-q_{1}\right)-C\left(S(I)-q_{1}\right)}{(1+r)^{2}}
$$

This leads to tax revenue whose present value is:

$$
T\left(\tau_{0}, \tau_{1}, \tau_{2}\right)=-\tau_{0} I+\tau_{1} \frac{p_{1} q_{1}-C\left(q_{1}\right)}{1+r}+\tau_{2} \frac{p_{2}\left(S(I)-q_{1}\right)-C\left(S(I)-q_{1}\right)}{(1+r)^{2}}
$$

Assume the objective function of the government is quasilinear in tax revenues, $W(\Pi)+$ $T\left(\tau_{0}, \tau_{1}, \tau_{2}\right)$, where $W^{\prime}(\Pi)>0>W^{\prime \prime}(\Pi)$. This captures in the simplest way the idea that the government puts at least some weight on producers' after-tax profits. ${ }^{25}$

\footnotetext{
${ }^{25}$ In many contexts, especially in developing countries, these profits will accrue largely to foreigners. This suggests an objective function of maximizing tax revenue subject to assuring foreign investors some minimum return (for fear perhaps that they will invest elsewhere instead). This leads to essentially the same conclusions as follow.
} 


\section{The time consistency of rent taxation}

Suppose first that the government announces its tax policy before the firm invests and can commit not to change the parameters of a cash-flow tax whose rate is $\tau_{0}$ in the investment period and $\tau_{1}$ and $\tau_{2}$ during the periods of extraction. Solving the problem by backward induction, the firm's problem is $\max _{\left\{I, q_{1}\right\}} \Pi$, giving the first-order conditions:

$$
\begin{aligned}
& -\left(1-\tau_{0}\right)+\left(1-\tau_{2}\right) \frac{p_{2}-C^{\prime}\left(q_{2}\right)}{(1+r)^{2}} S^{\prime}(I)=0 \\
& \left(1-\tau_{1}\right) \frac{p_{1}-C^{\prime}\left(q_{1}\right)}{1+r}-\left(1-\tau_{2}\right) \frac{p_{2}-C^{\prime}\left(q_{2}\right)}{(1+r)^{2}}=0 .
\end{aligned}
$$

The solution is $I\left(\tau_{0}, \tau_{1}, \tau_{2}\right)$ and $q_{1}\left(\tau_{0}, \tau_{1}, \tau_{2}\right)$, which gives the profit function $V\left(\tau_{0}, \tau_{1}, \tau_{2}\right)$, where, by the envelope theorem, and denoting derivatives by subscripts,

$$
V_{0}=I, \quad V_{1}=-\frac{p_{1} q_{1}-C\left(q_{1}\right)}{1+r}, \quad V_{2}=-\frac{p_{2} q_{2}-C\left(q_{2}\right)}{(1+r)^{2}}
$$

In this full commitment case the government then chooses $\left(\tau_{0}, \tau_{1}, \tau_{2}\right)$ to maximize $W\left(V\left(\tau_{0}, \tau_{1}, \tau_{2}\right)\right)+T\left(\tau_{0}, \tau_{1}, \tau_{2}\right)$. Using the envelope results (25) and the first-order conditions of the firm (23) and (24), the first-order conditions of the government's problem may be written:

$$
\begin{gathered}
\left(W^{\prime}-1\right) I-\left(\tau_{0}-\tau_{2} \frac{1-\tau_{0}}{1-\tau_{2}}\right) I_{0}+\left(\tau_{1} \frac{1-\tau_{0}}{1-\tau_{1}}-\tau_{2} \frac{1-\tau_{0}}{1-\tau_{2}}\right) \frac{q_{10}}{S^{\prime}}=0 \\
-\left(W^{\prime}-1\right) \frac{p_{1} q_{1}-C\left(q_{1}\right)}{1+r}-\left(\tau_{0}-\tau_{2} \frac{1-\tau_{0}}{1-\tau_{2}}\right) I_{1}+\left(\tau_{1} \frac{1-\tau_{0}}{1-\tau_{1}}-\tau_{2} \frac{1-\tau_{0}}{1-\tau_{2}}\right) \frac{q_{11}}{S^{\prime}}=0 \\
-\left(W^{\prime}-1\right) \frac{p_{2} q_{2}-C\left(q_{2}\right)}{(1+r)^{2}}-\left(\tau_{0}-\tau_{2} \frac{1-\tau_{0}}{1-\tau_{2}}\right) I_{2}+\left(\tau_{1} \frac{1-\tau_{0}}{1-\tau_{1}}-\tau_{2} \frac{1-\tau_{0}}{1-\tau_{2}}\right) \frac{q_{12}}{S^{\prime}}=0
\end{gathered}
$$

where $I_{i}$ and $q_{1 i}$ are derivatives of $I\left(\tau_{0}, \tau_{1}, \tau_{2}\right)$ and $q_{1}\left(\tau_{0}, \tau_{1}, \tau_{2}\right)$ with respect to the $i$ th argument. These necessary conditions are satisfied at $\tau_{0}=\tau_{1}=\tau_{2}$ and $W^{\prime}=1$. Not surprising, this full-commitment case involves a constant rent tax, which is non-distorting, and whose level is determined by $W^{\prime}=1$, so the marginal value of revenues is identical to the firm and the government. (The rate of rent taxation will be strictly positive at the first best if, as we assume to be the case, $W^{\prime}<1$ when all resource revenues accrue to the firm.)

We can verify that this outcome is time-consistent: that is, the government would not change policies if given a chance to re-optimize at the end of period 0. Suppose the government 
announced the above cash-flow tax policy and the firm chose $I$ assuming the government would not renege. Consider the government's optimal choice of $\tau_{1}$ and $\tau_{2}$ after the firm has chosen $I$. The government anticipates that the firm's choice of $q_{1}$ will maximize quasi-rents

$$
\pi=\left(1-\tau_{1}\right) \frac{p_{1} q_{1}-C\left(q_{1}\right)}{1+r}+\left(1-\tau_{2}\right) \frac{p_{2}\left(S(I)-q_{1}\right)-C\left(S(I)-q_{1}\right)}{(1+r)^{2}}
$$

This satisfies the first-order condition (24), and gives a value function, or quasi-rent function, $v\left(\bar{\tau}_{0}, \tau_{1}, \tau_{2}\right)$. The government chooses $\tau_{1}$ and $\tau_{2}$ to maximize $W\left(v\left(\bar{\tau}_{0}, \tau_{1}, \tau_{2}\right)\right)+$ $T\left(\bar{\tau}_{0}, \tau_{1}, \tau_{2}\right)$, where $I$ is given. The solution to this problem readily yields $\tau_{1}=\tau_{2}$ and $W^{\prime}=1$, implying that the government does not change its tax policy. In particular, it continues to set $\tau_{1}=\tau_{2}=\tau_{0}$.

By the same argument, the government would have no incentive to change its tax rate $\tau_{2}$ after period 1 when the firm has chosen $q_{1}$, and has no further decisions to take. Since its announced value of $\tau_{2}$ induces $W^{\prime}=1$, the government will only reduce welfare if it changes $\tau_{2}$. Thus, not only is cash-flow resource taxation efficient, it is also time-consistent.

\section{Time inconsistency and royalties}

Suppose now the government uses a system of royalties rather than cash-flow taxes. Begin with the case where the government selects per unit royalties of $\theta_{t}$ to apply to the quantity of extraction $q_{t}$ in period $t$, and also subsidizes initial investment at the rate $\sigma$. Given full-loss offsetting and using $q_{2}=S(I)-q_{1}$, the after-tax profit of the firm is

$$
\Pi=-(1-\sigma) I+\frac{\left(p_{1}-\theta_{1}\right) q_{1}-C\left(q_{1}\right)}{1+r}+\frac{\left(p_{2}-\theta_{2}\right)\left(S(I)-q_{1}\right)-C\left(S(I)-q_{1}\right)}{(1+r)^{2}}
$$

This leads to tax revenue whose present value is:

$$
T\left(\sigma, \theta_{1}, \theta_{2}\right)=-\sigma I+\frac{\theta_{1} q_{1}}{1+r}+\frac{\theta_{2}\left(S(I)-q_{1}\right)}{(1+r)^{2}}
$$

We continue to assume that the objective of the government is quasilinear in tax revenues, $W(\Pi)+T\left(\sigma, \theta_{1}, \theta_{2}\right)$.

Suppose first that the government announces a tax policy $\left(\sigma, \theta_{1}, \theta_{2}\right)$ before the firm invests and can commit not to change tax rates. Solving the problem by backward induction, the firm's problem is $\max _{I, q_{1}} \Pi$, giving the first-order conditions:

$$
-(1-\sigma)+\frac{p_{2}-\theta_{2}-C^{\prime}\left(q_{2}\right)}{(1+r)^{2}} S^{\prime}(I)=0
$$




$$
\frac{p_{1}-\theta_{1}-C^{\prime}\left(q_{1}\right)}{(1+r)}+\frac{p_{2}-\theta_{2}-C^{\prime}\left(q_{2}\right)}{(1+r)^{2}}=0 .
$$

The solution gives $I\left(\sigma, \theta_{1}, \theta_{2}\right)$ and $q_{1}\left(\sigma, \theta_{1}, \theta_{2}\right)$, and the profit function $V\left(\sigma, \theta_{1}, \theta_{2}\right)$, where, by the envelope theorem,

$$
V_{\sigma}=I, \quad V_{\theta 1}=-\frac{q_{1}}{1+r}, \quad V_{\theta 2}=-\frac{q_{2}}{(1+r)^{2}}
$$

The government then chooses $\left(\sigma, \theta_{1}, \theta_{2}\right)$ to maximize $W\left(V\left(\sigma, \theta_{1}, \theta_{2}\right)\right)+T\left(\sigma, \theta_{1}, \theta_{2}\right)$. Using the envelope results (29), the first-order conditions may be written:

$$
\begin{aligned}
& \left(W^{\prime}-1\right) I-\left(\sigma-\frac{\theta_{2} S^{\prime}}{(1+r)^{2}}\right) I_{\sigma}+\left(\frac{\theta_{1}}{1+r}-\frac{\theta_{2}}{(1+r)^{2}}\right) q_{1_{\sigma}}=0 \\
& -\left(W^{\prime}-1\right) \frac{q_{1}}{1+r}-\left(\sigma-\frac{\theta_{2} S^{\prime}}{(1+r)^{2}}\right) I_{\theta_{1}}+\left(\frac{\theta_{1}}{1+r}-\frac{\theta_{2}}{(1+r)^{2}}\right) q_{1_{\theta_{1}}}=0 \\
& -\left(W^{\prime}-1\right) \frac{q_{2}}{(1+r)^{2}}-\left(\sigma-\frac{\theta_{2} S^{\prime}}{(1+r)^{2}}\right) I_{\theta_{2}}+\left(\frac{\theta_{1}}{1+r}-\frac{\theta_{2}}{(1+r)^{2}}\right) q_{1_{\theta_{2}}}=0
\end{aligned}
$$

These will be satisfied at:

$$
W^{\prime}=1, \quad \theta_{1}=\frac{\theta_{2}}{1+r}, \quad \sigma=\frac{\theta_{2} S^{\prime}}{(1+r)^{2}}=\frac{\theta_{1} S^{\prime}}{1+r}
$$

This yields the first-best optimum, and is equivalent to the cash-flow tax. The royalty rate increases at the interest rate, $\left(\theta_{2}-\theta_{1}\right) / \theta_{1}=r$, which—as discussed above-entails that the path of extraction is optimum, while the subsidy ensures an optimal investment decision. Since the policy is first-best, it is time-consistent, so, as with the cash-flow tax, commitment is not necessary.

Suppose now that the government does not subsidize $I$ but only imposes royalties $\theta_{1}$ and $\theta_{2}$ on production. The problem of the firm is now to choose $I$ and $q_{1}$ to maximize after-royalty profits $\Pi$, where $\Pi$ is given by (26) with $\sigma=0$. The first-order conditions are the same as (27) and (28) with $\sigma=0$. The solution gives $I\left(\theta_{1}, \theta_{2}\right)$ and $q_{1}\left(\theta_{1}, \theta_{2}\right)$, where

$$
I_{\theta_{1}}<0, \quad I_{\theta_{2}}<0, \quad q_{1_{\theta_{1}}}<0, \quad q_{1_{\theta_{2}}}<0
$$

and the value function $V\left(\theta_{1}, \theta_{2}\right)$, where $V_{\theta 1}$ and $V_{\theta 2}$ are as in (29). 
The government's full-commitment problem, given the absence of a subsidy to initial investment, is to choose $\theta_{1}$ and $\theta_{2}$ to maximize $W\left(V\left(\theta_{1}, \theta_{2}\right)\right)+T\left(\theta_{1}, \theta_{2}\right)$. The first-order conditions for this can be written as follows:

$$
\begin{aligned}
& -\left(W^{\prime}-1\right) \frac{q_{1}}{1+r}+\frac{\theta_{2} S^{\prime}}{(1+r)^{2}} I_{\theta_{1}}+\left(\frac{\theta_{1}}{1+r}-\frac{\theta_{2}}{(1+r)^{2}}\right) q_{1_{\theta_{1}}}=0 \\
& -\left(W^{\prime}-1\right) \frac{q_{2}}{(1+r)^{2}}+\frac{\theta_{2} S^{\prime}}{(1+r)^{2}} I_{\theta_{2}}+\left(\frac{\theta_{1}}{1+r}-\frac{\theta_{2}}{(1+r)^{2}}\right) q_{1_{\theta_{2}}}=0 .
\end{aligned}
$$

Now the government cannot achieve the first-best outcome: that requires $W^{\prime}=1$ and $\theta_{1}=\theta_{2} /(1+r)$, which, since $S^{\prime} I_{\theta_{t}}<0$, is incompatible with (34)-(35). ${ }^{26}$ Indeed, starting with a set of royalties that satisfy these first-best conditions, a small reduction in each royalty rate will increase the value of the government's objective function. That is, the partial derivatives of $W\left(V\left(\theta_{1}, \theta_{2}\right)\right)+T\left(\theta_{1}, \theta_{2}\right)$ with respect to $\theta_{1}$ and $\theta_{2}$ give the lefthand sides of (34) and (35), which are negative when $W^{\prime}=1$ and $\theta_{1}=\theta_{2} /(1+r)$. The government is discouraged from setting royalties sufficiently high to divert income from the firm to itself such that $W^{\prime}=1$. It takes account of the fact that the royalty system discourages initial investment. One might expect that the optimal level of royalties will then leave after-tax profits higher than at the first best, so that $W^{\prime}<1$. As shown in the Appendix, that is indeed the case.

Suppose now that the government — still with only the two royalty rates at its disposal, and still taking $I$ and hence the resource stock as given-is unable to commit to its future policies. To solve for the time consistent equilibrium, note first that when period 2 arrives $q_{1}$ has been predetermined by the firm's decision in period 1; and that also, combined with the initial stock, predetermines $q_{2}$. So long as $q_{2}>0$, the optimal choice of $\theta_{2}$ is then such that

$$
W^{\prime}=1
$$

the reason being that the fixed tax base means that the government in effect has a lump sum tax at its disposal. In period 1 , maximizing with respect to $\theta_{1}$ gives (34) above with the difference that with $I$ predetermined the second term on the left does not appear. Using (36), this implies that

$$
\theta_{1}=\frac{\theta_{2}}{1+r}
$$

\footnotetext{
${ }^{26}$ Recalling too that tax revenue is assumed to be strictly positive at the first best, which rules out $\theta_{1}=\theta_{2}=0$.
} 
Two conclusions follow. The first is that, since the sensitivity of investment to expected royalties makes (36)-(37) inconsistent with (34)-(35), the full commitment royalty-only policy is time inconsistent: this is because it does not achieve a first-best, since it does not include a subsidy on investment. Compared with the full-commitment policy choice, the government has an incentive to increase royalty rates once investment is in place so as to achieve its objective of setting $W^{\prime}=1$. The second conclusion, recalling that (37) is the condition for the path of royalties not to distort extraction decisions, is that the time consistent royalty-only policy, while of course also not first best (because investment remains distorted), is efficient conditional on the initial stock of resources: in effect, the government has a credible incentive to maximize quasi-rents even though rents more broadly have been dissipated by the inability to subsidize investment. ${ }^{27}$

\section{Lessons}

This analysis would readily generalize to the case where there are several periods of production. The royalty policy chosen to maximize quasi-rents at the beginning of period 1 , that is, after investment has been undertaken, will be time-consistent in the sense that the government would not change its royalty rates in some later period. That is because, given $I$, the path of royalty rates is fully efficient: it maximizes quasi-rents. On the other hand, if the royalty rates are constrained so that the rate of extraction is not optimal-for example, if royalty rates must be constant over time - the full-commitment choice of royalty rates would not be time-consistent: the government would in the event wish to set the royalty rate at a level different from that which would be optimal if it could commit. This further highlights the advantage of rent taxes over royalties. All the rent tax schemes considered earlier-cashflow taxation, and the ACE and RRT schemes-are time-consistent because they yield the first-best outcome. Not only is this superior to the full-commitment royalty scheme, it is even more so compared to the time-consistent royalty scheme.

More generally, anything that causes the policy scheme that is optimal when the government can commit to deviate from the first-best will result in that policy being time-inconsistent. This will be the case if the government and the firm have different discount rates, for example, or if the host government has borrowing constraints. There may also be other distorting sources of revenue that are made use of in the full-commitment optimum.

\footnotetext{
${ }^{27}$ The marginal conditions (36) and (37) are the same as those for the full first best, inclusive of the investment choice, and indeed (36) implies that after-tax profits are the same in the two cases. The loss in the government's objective function from the inabilities to subsidize investment and to commit are felt, given the assumption here on its functional form, entirely in reduced tax revenue.
} 


\section{CONCLUding REMARKS}

This paper has explored the comparative properties of rent taxes and royalties as devices for the capture of natural resource rents by the government. The model used was stylized so as to capture some key features of the discovery and exploitation of non-exhaustible natural resources: an initial investment phase followed by extraction and, eventually, shutdown. Resource prices and extraction costs were both uncertain, while for simplicity the stock of resources obtained from initial investment was assumed to be deterministic. In a setting where the no-tax equilibrium was efficient, we showed how rent taxes could be designed so as to capture revenue without distorting any of the choices made by the firm, including investment, the rate of extraction, and the time of shutdown. These included not only the classic cash-flow and Brown taxes, but also two much wider classes of tax-the ACE and RRT families_ — of which they are special cases.

Royalties, on the other hand, are distortionary. While in principle a royalty scheme could be designed that would induce an optimal extraction path, such a scheme would be virtually impossible to implement because it would be contingent on future prices and would differ from firm to firm. In addition, the time of shutdown would be distorted; and initial investment would be discouraged unless an appropriate initial subsidy was also deployed. Moreover, the fully optimal royalty scheme would also be time-inconsistent (unless accompanied by a subsidy to initial investment), as the government would have an incentive to increase royalty rates above the full-commitment level after investment costs had been sunk; time consistent royalty policy is efficient, however, conditional on the initial stock of resources.

If the no-tax equilibrium were inefficient, resource tax policies could be adjusted to counter the distortions. We considered various cases. In one, the government's discount rate differed from that of the resource firms, an effect that could be offset-though at the price of causing other distortions, unless further instruments can be deployed-by an appropriate time path of royalties. In another, the finite duration of contracts creates an incentive for excessively fast extraction that suitable royalties can again counter. And in a third, differing degrees of risk aversion between government and firms implied scope for mutual benefit by incorporating some degree of non-linearity in the taxation of rents. Asymmetries of information between government and firm were seen to imply still more subtlety in instrument design: they generally call for a menu of combinations of royalty rate and fee (equivalent in effect to a non-linear rent tax) serving to ease the self-selection constraints that impede an efficient allocation of resources; and, more prosaically, they can also warrant deploying both instruments in order to best cope with possibilities of avoidance and evasion though the misstatement or manipulation of costs.

The treatment has been limited to what seem to us the key insights from the literature, and leaves many open questions. An important one is why governments typically only take a 
limited portion of the rents. In principle, where natural resources are publicly owned, there seems to be no reason why government should not aim to capture all the rents. Various explanations suggest themselves. Governments may perceive themselves to be subject to pressures from international tax competition, although, since natural resources are not mobile it is by no means clear why that should be the case. There may be political economy explanations having to do with the clout of large natural resource companies. Reduced taxation of natural resources once discovered and developed may be called for to the extent that taxes cannot be designed in a way that does not discourage initial investment. Royalties, as we have seen, will distort initial investment, and restraining royalty rates may be one politically acceptable way to limit that distortion. Similarly, when rent taxes are used, it may be difficult for governments to provide credible assurance that all losses will eventually be offset, especially for exploration firms that wind up before making any profit.

Why governments use distorting policy instruments like royalties and imperfect profits taxes also remains unexplained. As we have suggested, asymmetric information may be part of the reason. There are, no doubt, political economy considerations. Royalties, for instance, have the attraction of ensuring that the government can show to its electorate a steady flow of revenues from resource firms as soon as production begins. And some degree of profitsensitivity may help reduce the risk of political pressures to renegotiate contracts when earnings are high. While we believe the results presented here have real practical value, there thus remains much that is imperfectly understood. 


\section{Appendix}

\section{Proof that $W^{\prime}<1$ in full commitment case with only royalties}

Assume for simplicity that extraction costs are independent of the stock of the resource $S$. Since $S=q_{1}+q_{2}$, we can write the firm's after-tax profits as

$$
\Pi=-I\left(q_{1}+q_{2}\right)+\frac{p_{1} q_{1}-C^{\prime}\left(q_{1}\right)}{1+r}-\theta_{1}^{*} q_{1}+\frac{p_{2} q_{2}-C^{\prime}\left(q_{2}\right)}{(1+r)^{2}}-\theta_{2}^{*} q_{2}
$$

where $\theta_{i}^{*}=\theta_{i} /(1+r)$. The firm's profit function is $V\left(\theta_{1}^{*}, \theta_{2}^{*}\right)$, with $V_{i}=-q_{i}$ for $i=1,2$. The first-order conditions for the firm are:

$$
q_{i}=-I^{\prime}+\frac{p_{i}-C^{\prime}\left(q_{i}\right)}{(1+r)^{2}}-\theta_{i}^{*}=0, \quad i=1,2
$$

The solution to these yields $q_{i}\left(\theta_{1}^{*}, \theta_{2}^{*}\right)$, where these extraction functions capture the impact of royalties on initial investment $I$. Differentiating the first-order conditions yields after straightforward simplification:

$$
\left[\begin{array}{l}
d q_{1} \\
d q_{2}
\end{array}\right]=\frac{1}{\Delta}\left[\begin{array}{cc}
-I^{\prime \prime}-\frac{C^{\prime \prime}\left(q_{2}\right)}{1+r} & I^{\prime \prime} \\
I^{\prime \prime} & -I^{\prime \prime}-\frac{C^{\prime \prime}\left(q_{1}\right)}{1+r}
\end{array}\right]\left[\begin{array}{l}
d \theta_{1}^{*} \\
d \theta_{2}^{*}
\end{array}\right]
$$

Where

$$
\Delta=\left(I^{\prime \prime}+\frac{C^{\prime \prime}\left(q_{1}\right)}{1+r}\right)\left(I^{\prime \prime}+\frac{C^{\prime \prime}\left(q_{2}\right)}{1+r}\right)-\left(I^{\prime \prime}\right)^{2}>0
$$

This implies that

$$
\frac{\partial q_{1}}{\partial \theta_{i}^{*}}+\frac{\partial q_{2}}{\partial \theta_{i}^{*}}<0
$$

The government objective function is $W\left(V\left(\theta_{1}^{*}, \theta_{2}^{*}\right)\right)+\theta_{1}^{*} q_{1}\left(\theta_{1}^{*}, \theta_{2}^{*}\right)+\theta_{2}^{*} q_{2}\left(\theta_{1}^{*}, \theta_{2}^{*}\right)$, whose first-order conditions can be written:

$$
\left(W^{\prime}-1\right) q_{i}=\theta_{1}^{*} \frac{\partial q_{1}}{\partial \theta_{i}^{*}}+\theta_{2}^{*} \frac{\partial q_{2}}{\partial \theta_{i}^{*}} \quad i=1,2
$$

Combining the conditions for $i=1,2$, we obtain:

$$
\left(W^{\prime}-1\right)\left(q_{1}+q_{2}\right)=\theta_{1}^{*}\left(\frac{\partial q_{1}}{\partial \theta_{i}^{*}}+\frac{\partial q_{2}}{\partial \theta_{i}^{*}}\right)+\theta_{2}^{*}\left(\frac{\partial q_{1}}{\partial \theta_{i}^{*}}+\frac{\partial q_{2}}{\partial \theta_{i}^{*}}\right)
$$

Assuming $\theta_{i}^{*} \geq 0$, with at least one strictly positive, (A.1) and (A.2) imply that $W^{\prime}<1$. 


\section{REFERENCES}

Auerbach, Alan J., 1979, “Wealth maximization and the cost of capital,” Quarterly Journal of Economics 93, pp. 433-46. , 1983, “Taxation, corporate financial policy and the cost of capital,” Journal of Economic Literature 21, pp. 905-40.

Michael P. Devereux, and Helen Simpson, 2008, “Taxing corporate income,” background paper for the Mirrlees Review, Reforming the Tax System for the 21st Century.

Australian Treasury (The Henry Report), 2010. Australia's Future Tax System. (Canberra: Commonwealth of Australia).

Boadway, Robin and Neil Bruce, 1984, “A general proposition on the design of a neutral business tax,” Journal of Public Economics 24, pp. 231-39 , and Michael Keen, 2010, “Theoretical perspectives on resource tax design,” in Daniel, P., Keen, M. and C. McPherson, eds., The Taxation of Petroleum and Minerals: Principles, Problems and Practice (London: Routledge), pp. 13-74.

Bohn, Henning, and Robert T. Deacon, 2000, “Ownership Risk, Investment, and the Use of Natural Resources,” American Economic Review, Vol. 90, pp. 526-49.

Bond, Stephen R. and Michael P. Devereux, 1995, "On the design of a neutral business tax under uncertainty,” Journal of Public Economics 58, pp.57-71.

Bond, Stephen R. and Michael P. Devereux, 2003, “Generalised R-based and S-based taxes under uncertainty,” Journal of Public Economics 87, pp.1291-1311.

Brown, E. Cary, 1948, “Business-income taxation and investment incentives,” in Income, Employment and Public Policy: Essay in Honor of Alvin H. Hansen, New York: Norton.

Busby, Colin, Benjamin Dachis and Bev Dahlby, 2011, "Rethinking Royalty Rates: Why There Is a Better Way to Tax Oil and Gas Development,” Commentary No. 333, C.D. Howe Institute, Toronto.

Calvo, Guillermo and Maurice Obstfeld, 1988, “Optimal Time-Consistent Fiscal Policy with Finite Lifetimes,” Econometrica, Vol. 56, pp. 411-432. 
Calder, Jack (forthcoming), Natural Resource Revenue Administration Handbook (IMF and World Bank: Washington DC).

Conrad, Robert and Bryce Hool, 1981, "Resource taxation with heterogeneous quality and endogenous reserves,” Journal of Public Economics, Vol. 16, pp.17-33.

Conrad, Robert, Bryce Hool and Denis Nekipelov, 2009, “The role of royalties in natural resource extraction contracts,” mimeo.

Cramton, Peter, 2007, “How best to auction oil rights,” in Macartan Humphreys, Jeffrey D. Sachs, Joseph E. Stiglitz (eds.), Escaping the Resource Curse, Chapter 5, pp.114-151, New York: Columbia University Press.

Daniel, Philip, 1995, “Evaluating state participation in mineral projects: Equity, infrastructure projects and taxation,” pp.165-187 in James Otto (ed) The Taxation of Mineral Enterprises (Graham \& Trotman: London).

, Michael Keen, and Charles McPherson, eds., 2010, The Taxation of Petroleum and Minerals: Principles, Problems and Practice (London: Routledge).

Dasgupta, Partha S. and Geoffrey M. Heal, 1979, Economic Theory and Exhaustible Resources (Cambridge University Press: Cambridge).

Daubanes, Julien and Pierre Lasserre, 2011, “Optimum commodity taxation with a nonrenewable resource,” Scientific series 2011s-05, CIRANO, Montreal.

De Mooij, Ruud, 2012, “Tax biases to debt finance: Assessing the problem, finding solutions," Fiscal Studies, Vol. 33, pp. 489-512.

Garnaut, Ross and Anthony Clunies-Ross, 1975, "Uncertainty, risk aversion and the taxing of natural resource projects,” Economic Journal, Vol. 85, pp. 272-287.

Garnaut, Ross and Anthony Clunies-Ross, 1983, Taxation of Mineral Rents (Clarendon Press: Oxford).

Heaps, Terry and John F. Helliwell, 1985, “Taxation of natural resources,” pp 421-472 in Alan Auerbach and Martin Feldstein (eds) Handbook of Public Economics (North Holland: Amsterdam), Vol. 1.

Hillier, Brian and James Malcomson, 1984, "Dynamic Inconsistency, Rational Expectations, and Optimal Government Policy,” Econometrica, Vol. 52, pp.1437-1451. 
Hotelling, Harold, 1931,, “The Economics of Exhaustible Resources,” Journal of Political Economy, Vol. 39, pp. 137-175.

IFS Capital Taxes Group, 1991, "Equity for Companies: A Corporation Tax for the 1990s," Commentary No. 26, Institute for Fiscal Studies, London.

International Monetary Fund, 2012a, "Fiscal Regimes for Extractive Industries: Design and Implementation,” at http://www.imf.org/external/np/pp/eng/2012/081512.pdf.

, 2012b, "Macroeconomic policy frameworks for resource-rich developing countries," at www.imf.org/external/np/pp/eng/2012/082412.pdf

Klemm, Alexander, 2007, “Allowances for Corporate Equity in Practice,” CESifo Economic Studies, Vol. 53, pp.229-262.

Klemperer, Paul D., 2004, Auctions: Theory and Practice. Princeton: University Press.

Krautkraemer, Jeffrey A, 1999, “Nonrenewable resource scarcity,” Journal of Economic Literature, Vol. XXXVI, pp.2065-2107.

Lund, Diderik, 2005, "How to analyze the investment-uncertainty relationship in real option models?” Review of Financial Economics, Vol. 14, pp. 311-322.

, 2009, "Rent taxation for non-renewable resources”, Annual Review of Resource Economics, Vol. 1, pp. 287-308

Meade, James E., 1978, The Structure and Reform of Direct Taxation, Report of a Committee chaired by Professor J. E. Meade. London: George Allen \& Unwin.

Mintz, Jack and Duanjie Chen, 2012, "Capturing economic rents from resources through royalties and taxes,” School of Public Policy Research Papers, Volume 5, Issue 30, University of Calgary.

Osmundsen, Petter, 2005, "Optimal petroleum taxation—Subject to mobility and information constraints," in S. Glomsrød and P. Osmundsen (eds), Petroleum Industry Regulation within Stable States: Recent Economic Analysis of Incentives in Petroleum Production and Wealth Management, Ashgate Studies in Environmental and Natural Resource Economics, Ashgate.

, 2008, "Dynamic taxation of non-renewable natural resources under asymmetric information about reserves," Canadian Journal of Economics, Vol.31, pp. 933-951. 
, 2010, "Time consistency in petroleum taxation - the case of Norway," in Daniel, P., Keen, M. and C. McPherson, eds., The Taxation of Petroleum and Minerals:

Principles, Problems and Practice (London: Routledge), pp. 425-444.

Ramsey, Frank P., 1928, “A mathematical theory of saving,” Economic Journal, Vol. 38, pp. 543-559.

Sandmo, Agnar, 1979, "A note on the neutrality of the cash flow corporate tax," Economic Letters; Vol. 4, pp.173-176.

Smith, James, 2012a, "Issues in extractive resource taxation: A review of research methods and models,” IMF Working Paper 12/287. , 2012b, "Modeling the impact of taxes on petroleum exploration and development," IMF Working Paper 12/278.

van der Ploeg, Frederick, 2011, “Natural Resources: Curse or Blessing?,” Journal of Economic Literature, 49, 366-420.

Venables, Anthony J., 2010, "Resource rents; when to spend and how to save," International Tax and Public Finance, Vol. 17, pp. 340-356.

Weitzman, Martin L., 1974, “Prices versus quantities,” Review of Economic Studies, Vol. 41, pp. 477-91. 